\title{
Geochemistry and U-Pb ages of the diabases from the Luoji area, western Yunnan, China: implications for the timing of the initial rifting of the Ganzi-Litang Ocean
}

\author{
Chan Wang ${ }^{1,2}$, Hao Liu²,3,*, Hanbin Feng ${ }^{4}$, Jianghong Deng ${ }^{1}$, Xianfan Liu ${ }^{1}$ and Fufeng Zhao ${ }^{1}$ \\ ${ }^{1}$ Chengdu University of Technology, College of Earth Sciences, Chengdu, Sichuan, 610059, China \\ 2 School of Environment and Earth Science, University of Queensland, Brisbane, QLD, 4072, Australia \\ ${ }^{3}$ Chengdu University of Technology, College of Energy, State Key Laboratory of Oil and Gas Reservoir Geology and Exploitation, Chengdu Sichuan, 610059, China \\ ${ }^{4}$ North China Petroleum Administration Co., Ltd. Sulige Exploration and Development Branch, Shijiazhuang, Hebei, 017300, China \\ ( ${ }^{*}$ correspondence author: Hao Liu, 277515537@qq.com)
}

doi: $10.4154 / g c .2019 .25$

\section{Article history:}

Manuscript received May 13, 2019

Revised manuscript accepted August 28, 2019 Available online December 20, 2019

Keywords: Diabase, Ganzi-Litang Ocean, Luoji, Early Permian, Western Yunnan

\begin{abstract}
Detailed geochemical and U-Pb studies of two diabases (Luoji and Cuiyi) from the Luoji area have been undertaken. The diabases are high-K calc-alkaline and belonging to the tholeiitic series, enriched in large ion lithophile elements, $\mathrm{Ti}, \mathrm{Zr}$ and light rare earth elements, and depleted in high field strength elements. These characteristics are different from the oceanic island basalt but highly consistent with the continental rift basalt, indicating the Luoji and Cuiyi diabases are the products of the intracontinental rift related to the initial opening of the Ganzi-Litang Ocean. The Luoji and Cuiyi diabases originated from an enriched mantle source with a small degree of crustal contamination during their emplacement. Zircon $\mathrm{U}-\mathrm{Pb}$ ages show that the Luoji and Cuiyi diabases were emplaced at $293.4 \pm 5.4 \mathrm{Ma}$. Therefore, we propose that the time of initial rifting of the Ganzi-Litang Ocean occurred during the very Early Permian.
\end{abstract}

\section{INTRODUCTION}

Continental rift basalt (CRB) is one of the key geological records for understanding the mechanism and process of continental rifting (e.g., FREY et al., 1978; SUN \& MCDONOUGH, 1989; MACDONALD et al., 2001; CUI et al., 2015; MA et al., 2017). In rift environments, due to the interaction between tectonics and magmatism, the continental lithosphere usually undergoes substantial thinning, which inevitably leads to the upwelling of mantle magma (HAWKESWORTH et al., 1993; WANG et al., 2002; CUI et al., 2015; KHOSHNOODI et al., 2017; ZHOU et al., 2018). Consequently, at the beginning stage of rifting, mantle-derived magmas with signatures of CRB will emplace along the tensioned weak zone of a continental rift belt (MACDONALD et al., 2001; CUI et al., 2015; SZABÓ et al., 2016). A CRB is crucial to the study of the continental within-plate tectonic movement and the initial evolution of the ocean basin as it has a fundamental role in constraining the initiation time of the ocean opening (LASSITER \& DEPAOLO, 1997; JUNG \& MASBERG, 1998; CUI et al., 2015).
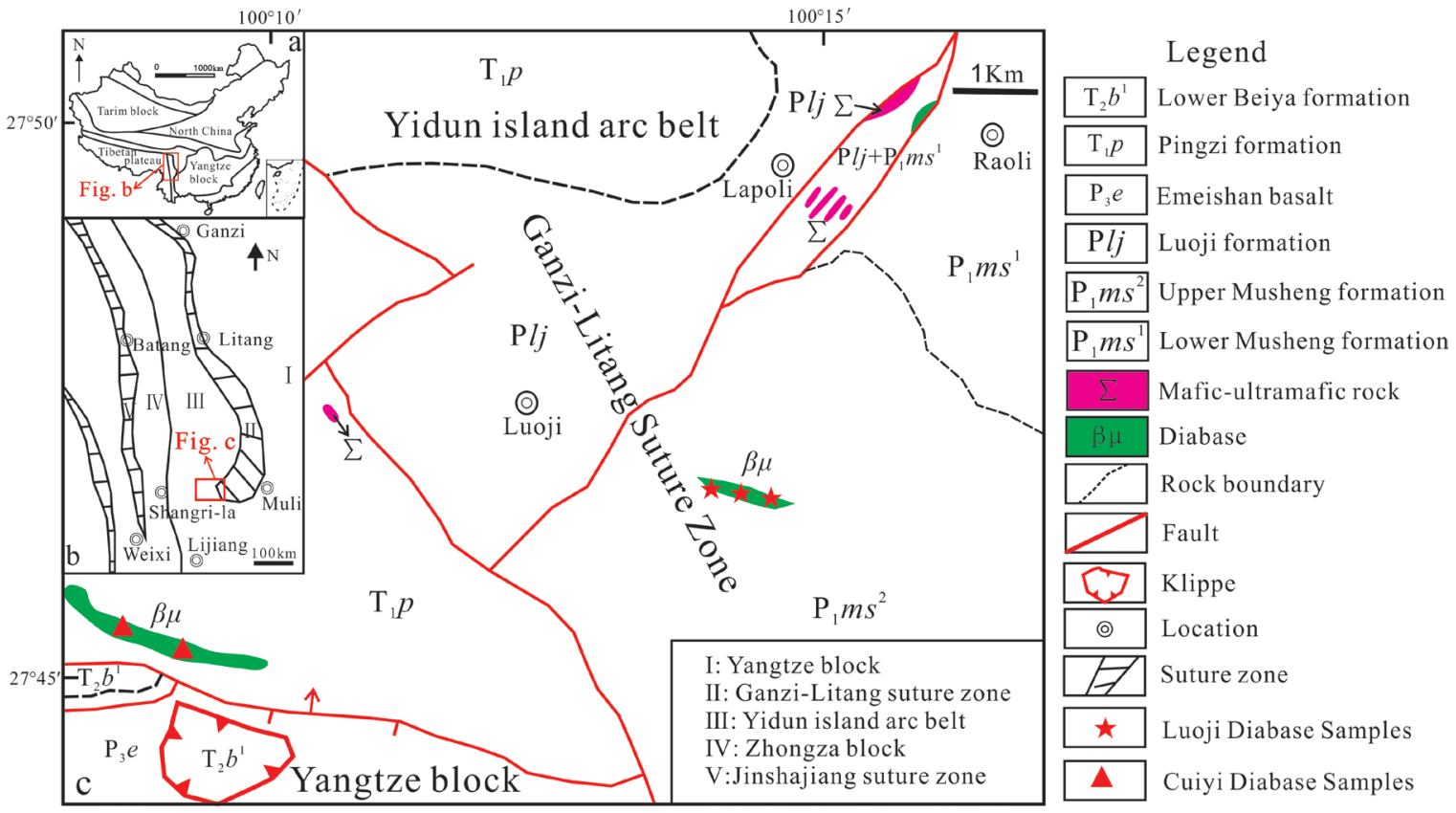

Figure 1. Location of the western Yunnan in China (a), geotectonic location map (b) and regional geological map of the Luoji diabase in western Yunnan province (c) (after HOU et al., 2001). 


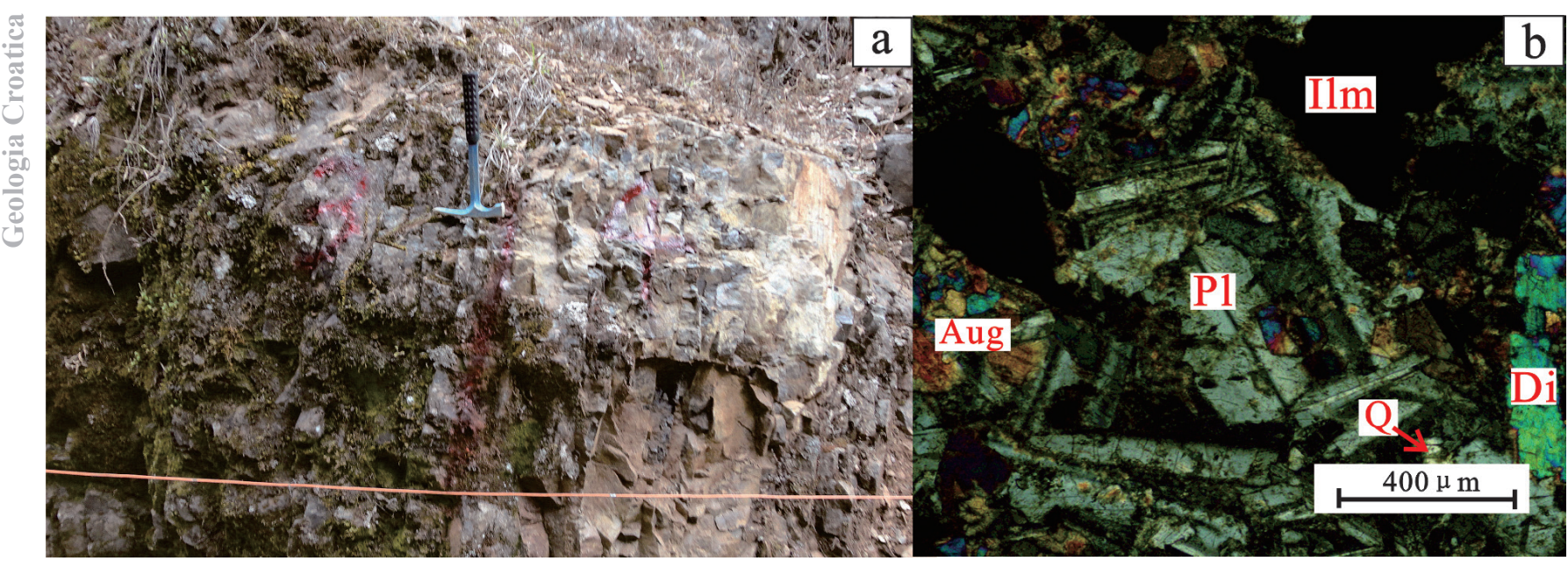

Figure 2. (a) Outcrop of diabase with a diabasic texture; (b) Photomicrograph of diabase (cross-polarized light). Ilm-ilmenite; Pl-plagioclase; Di-diopside; Aug-augite; Q-quartz.

The initial opening time of the Ganzi-Litang Ocean has always been controversial. In order to reveal the process of tectonic evolution with the Ganzi-Litang Ocean, mafic diabases developed in the Ganzi-Litang suture zone of Tibet have been extensively studied by earlier researchers (e.g., HOU et al., 2001; YBGMRRGST, 2003; LIANG et al., 2018). However, most of the reported diabases are oceanic island basalts (OIB) or mid-ocean ridge basalts (MORB) (HOU et al., 2001). Hence, the time of initial rifting of the Ganzi-Litang Ocean is still not well constrained.

In this research, we conducted whole-rock geochemistry and zircon U-Pb dating analysis of two diabases (Luoji and Cuiyi) from the Luoji area, the southern segment of the Ganzi-Litang suture zone. The diabases in this study show typical CRB characteristics, hence can be used to constrain the initial evolution of the Ganzi-Litang Ocean.

\section{GEOLOGICAL BACKGROUND AND LITHOFACIES CHARACTERISTICS}

The Luoji and Cuiyi diabases are located in the Luoji Country in the northwestern part of Shangri-La County, Yunnan Province, SW China. They are a part of the Ganzi-Litang Ocean basin and located at the junction of the western margin of the Yangtze block, the Zhongzan-Zhongdian continental block and the Yidun island arc belt (Fig. 1a). Magmatic activities in this area mainly occurred during Permian to Triassic time (HOU et al., 2001; YBGMRRGST, 2003; LIANG et al., 2018). Most of the ultrabasic-basic rocks have been deformed and transformed due to multi-stage tectonic movements. During the continental collision stage, most of the ultrabasicbasic rocks occur in the form of a mélange (YBGMRRGST, 2003).

The ultrabasic rocks in the study area occur in the Lower Permian Mushengtu Formation. Most of the basic rocks are dia-

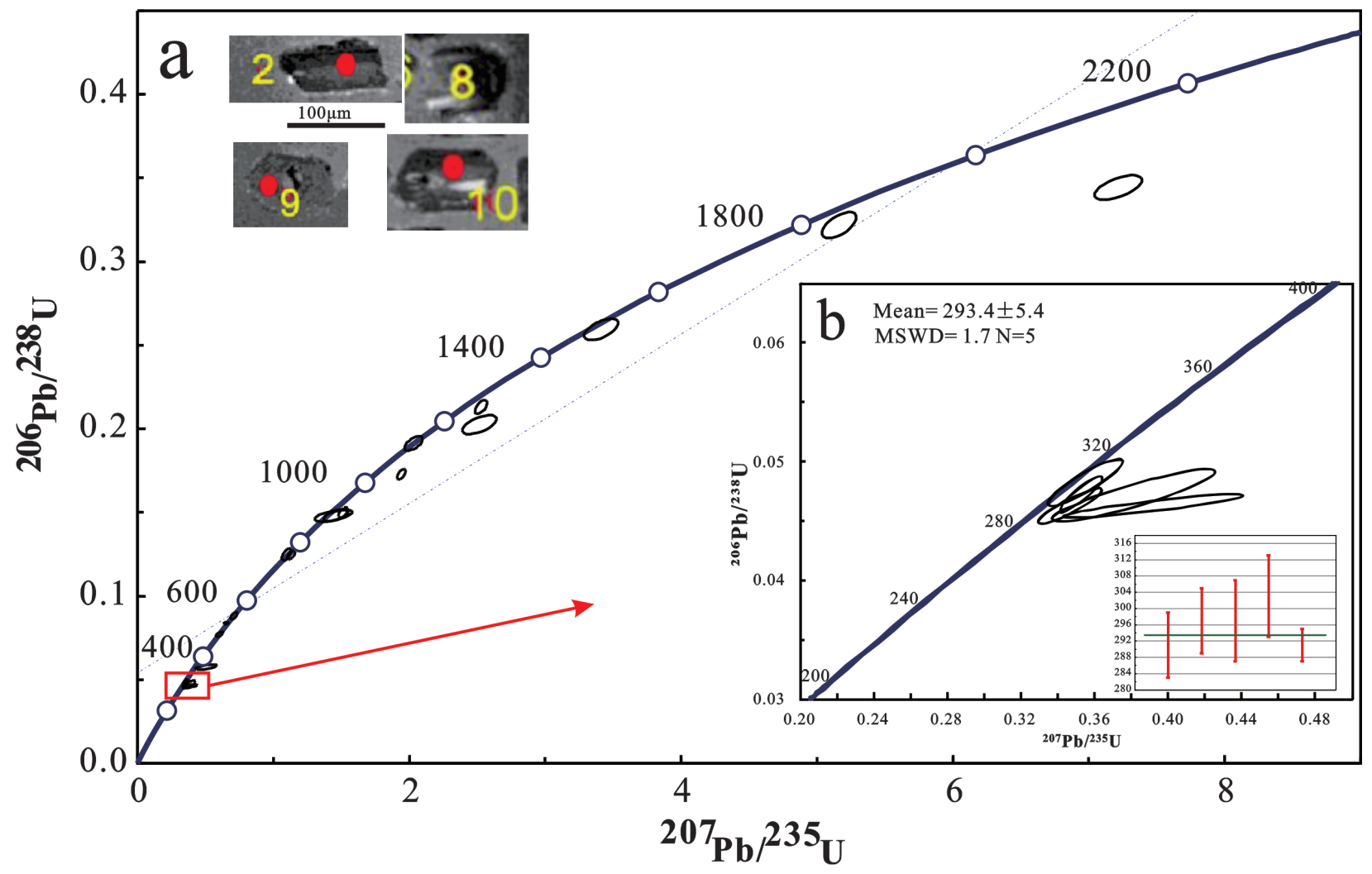

Figure 3. Zircon U-Pb concordia diagrams for the Luoji diabase. 
base dykes cropping out in the Lapoli, Sijiagou and Zhangjia areas. The dykes are distributed in NW-SE direction with a width ranging from tens of centimetres to a few metres and they extend for hundreds of metres. The diabases intruded into the Mushengtu Formation and the Lower Permian Luoji Formation (YBGMRRGST, 2003).

The Luoji and Cuiyi diabases are dark gray-grayish green (Fig. 2a), fine- to medium-grained (0.2 2mm.) with a diabasic texture. The rocks are composed of plagioclase (75 79\%), augite (5 8\%), diopside (2 5\%) and quartz (1\%) with accessory minerals of apatite, magnetite and ilmenite (Fig. 2b).

\section{SAMPLES AND METHODS}

Rock samples for this study were collected from outcrops. Only the fresh to least-altered samples were selected on the basis of hand lens observations for further analysis by thin- section.

Major and trace elements were analyzed at the Metallurgical Geological Rocks and Ore testing Center, Sichuan, China. For major element analyses, powder samples (grain size less than 200 mesh) were fluxed with $\mathrm{Li}_{2} \mathrm{~B}_{4} \mathrm{O}_{7}$ (1:8) to make homogeneous glass discs at $1,250^{\circ} \mathrm{C}$ using a V8C automatic fusion machine. The bulk rock major elements were analyzed on fused glass discs with a Zetium (PANalytical) sequential X-ray fluorescence spectrometer. The loss on ignition (LOI) of sample powders was determined at a temperature of $1,000^{\circ} \mathrm{C}$. The measurements were monitored using the standards GSR-3 (XIE et al., 1989) and BHVO-2 (RACZEK et al., 2010), and the accuracy of the analytical results was controlled by measuring the standard reference material BHVO2 . The analytical errors for the major element analyses were better than $2 \%$.

Trace element analyses were conducted using inductively coupled plasma mass spectrometry (ICP-MS) (Thermal X Series II). During the digestion procedure, $25 \mathrm{mg}$ of sample powder was precisely weighed and transferred into screw-top Teflon beakers. Then $1.5 \mathrm{ml} \mathrm{HF}$ and $1.5 \mathrm{ml} \mathrm{HNO}_{3}$ were added in turn and heated in the closed Teflon beakers at $100^{\circ} \mathrm{C}$ for 96 hours, subsequently opened and heated at $120^{\circ} \mathrm{C}$ to evaporate the dissolution. Then,

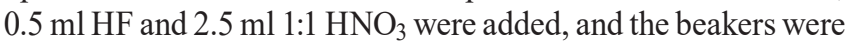
transferred to a digestion bomb. The bombs were heated in an oven at $170^{\circ} \mathrm{C}$ for 72 hours, after which the beakers were opened and heated at $120^{\circ} \mathrm{C}$ to evaporate the dissolutions. The residues were added to $1: 1 \mathrm{HNO}_{3}$, sealed and heated at $120^{\circ} \mathrm{C}$ for $30 \mathrm{~min}$.
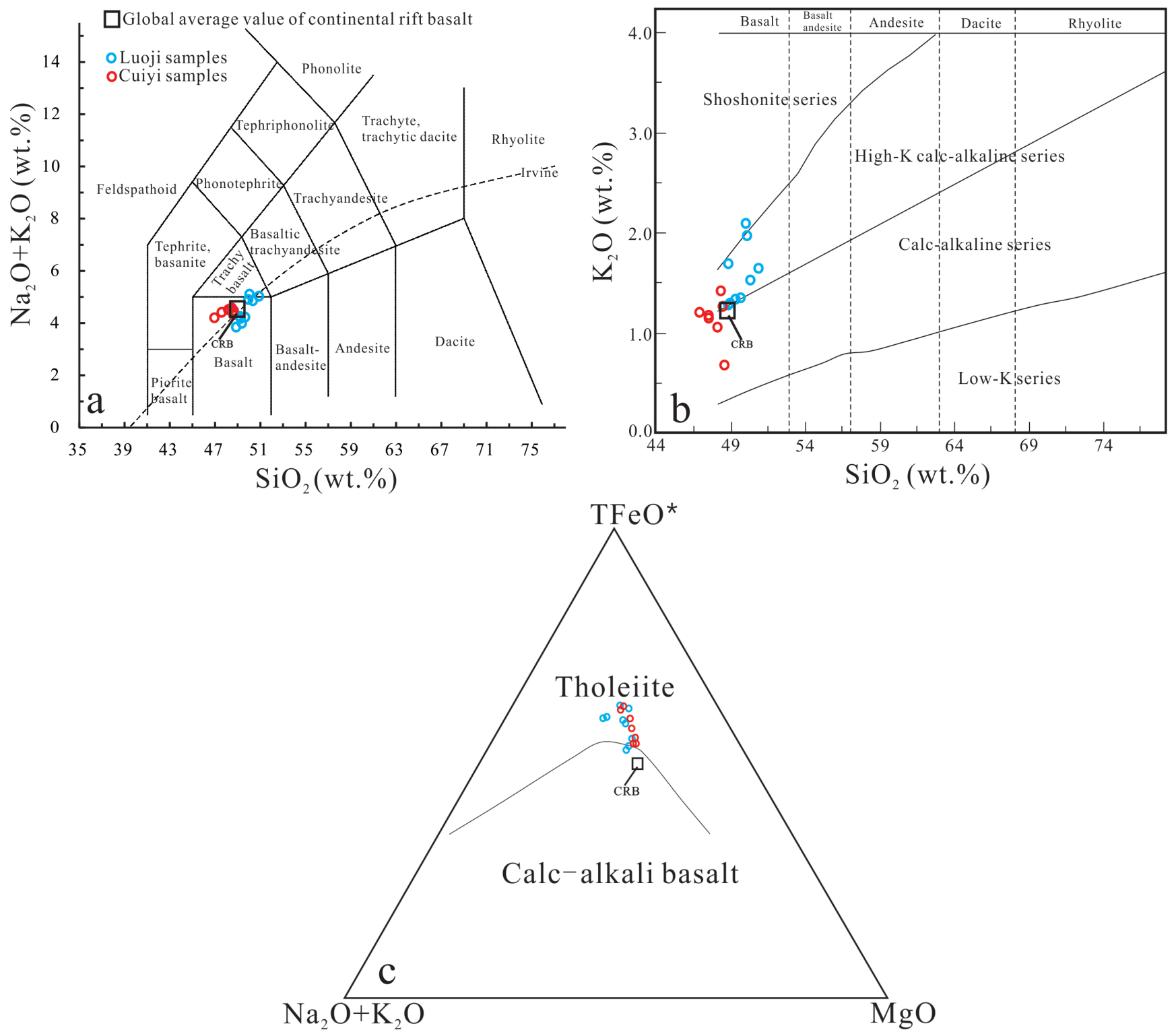

Figure 4. (a) $\mathrm{SiO}_{2}$ (wt.\%) vs. $\mathrm{Na}_{2} \mathrm{O}+\mathrm{K}_{2} \mathrm{O}$ (wt.\%) diagram (after PEARCE, 1979); (b) $\mathrm{SiO}_{2}$ (wt.\%) vs. $\mathrm{K}_{2} \mathrm{O}$ (wt.\%) diagram (after MANIAR \& PICCOLI, 1989); (c) Whole-rock alkali $\left(\mathrm{Na}_{2} \mathrm{O}+\mathrm{K}_{2} \mathrm{O}\right)$ vs. TFeO vs. MgO (AFM) plot for Luoji and Cuiyi samples (after IRVINE \& BARAGER, 1971). 
The solutions were then diluted 1,000 times using $2 \%$ distilled super-pure $\mathrm{HNO}_{3}$ and analyzed using ICP-MS with In, Rh and $\mathrm{Re}$ as inner standards. The standard solutions (American Lab Tech Company) were diluted to $1 \mu \mathrm{g} \mathrm{l}^{-1}, 10 \mu \mathrm{g} \mathrm{l}^{-1}, 50 \mu \mathrm{g} \mathrm{l^{-1 }}$, and $100 \mu^{\mathrm{g}^{-1}}$ to produce the calibration curve, with linear regression coefficients all above 0.9999 . The BHVO-2 and GSR-3 were run as external standards to evaluate the accuracy. Analytical precision for most elements is better than $3 \%$.

In order to constrain their emplacement time, zircon grains were handpicked from the diabases under a binocular microscope after conventional heavy liquid and magnetic separation, and then mounted in an epoxy resin. The sample mount was polished to expose the centres of the zircons. All of the grains were photographed under transmitted and reflected light and then examined using cathodoluminescence (CL) imaging to observe the internal structures of the zircons. U-Pb analyses of the zircons were carried out using an Agilent Technologies 7700x quadrupole ICPMS equipped with a $193 \mathrm{~nm} \mathrm{ArF} \mathrm{excimer} \mathrm{laser} \mathrm{at} \mathrm{the} \mathrm{Institute} \mathrm{of}$ Geophysical Geochemistry, Chinese Academy of Geological Sciences, Beijing. The laser beam was focused on the sample with a fluency of $5.0 \mathrm{~J} / \mathrm{cm}^{2}$ and a spot of $40 \mu \mathrm{m}$ diameter at a repetition rate of $5 \mathrm{~Hz}$ for $50 \mathrm{~s}$. Helium was used as a carrier gas to transport the ablated aerosol to the mass-spectrometer. Zircon Nancy 91500 (WEDENBECK et al., 1995) was used as an external calibration standard to correct for instrumental mass bias and elemental fractionation. The standard GJ-1 (JACKSON et al., 2004) was simultaneously analyzed which yielded ages consistent with the recommended values within analytical error. The $\mathrm{Pb}$ content of the zircon was externally calibrated against NIST SRM 610 with $\mathrm{Si}$ as an internal standard, whereas other trace elements were measured with $\mathrm{Zr}$ as an internal standard (HU et al., 2011). Rawdata reduction was performed off-line using the ICPMSDataCal (LIU et al., 2010). Concordia diagrams and weighted average calculations were made using Isoplot 3.0 (LUDWIG, 2012). Uncertainties in individual analyses are reported at the $1 \sigma$ level, and the average ages for pooled U-Pb analyses are quoted at $95 \%$ confidence.

\section{RESULTS}

\subsection{Zircon $\mathrm{U}-\mathrm{Pb}$ dating}

Cathodoluminescence (CL) images of representative zircon grains are shown in Figure 3. and LA-ICP-MS zircon U-Pb data are presented in Table 1. Twenty-one zircon grains from the diabases are mostly euhedral to subhedral, with lengths of $40-100 \mu \mathrm{m}$ and length-to-width ratios of 1:1 to 3:1, and have weak oscillatory zones indicating a magmatic origin. Zircon grains from the Luoji diabase have U contents of 215-1502 ppm (average 647.29), Th contents of 45-5824 ppm (average 1421.67) and $\mathrm{Th} / \mathrm{U}$ ratios from 0.11 to 5.80 (Table 3), indicating they are of magmatic origin. The single spot ages vary from $1907 \pm 17 \mathrm{Ma}$ to $291 \pm 4 \mathrm{Ma}$ with three distinctive peaks of $1245 \mathrm{Ma} \sim 1028 \mathrm{Ma}, 901 \mathrm{Ma} \sim 757 \mathrm{Ma}$ and 303Ma 291Ma. For the youngest set of data, the spots yield a ${ }^{206} \mathrm{~Pb} /{ }^{238} \mathrm{U}$ weighted mean age of $293.4 \pm 5.4 \mathrm{Ma}$ (Fig. 3b, MSWD $=1.7, \mathrm{~N}=5$ ), which indicate that the diabase was emplaced during the Early Permian.

\subsection{Major elements}

As shown in Table 2, the LOI values of the Luoji and Cuiyi diabases are between $0.41 \%$ and $4.87 \%$. The Luoji diabase may be slightly affected by alteration, so the normalized calculation is carried out after deducting the LOI (IRVINE \& BARAGAR,
1971). Luoji diabase samples contain $48.86 \sim 50.89 \mathrm{wt} . \% \mathrm{SiO}_{2}$ (average 49.68 wt.\%), 1.28 2.09 wt.\% $\mathrm{K}_{2} \mathrm{O}$ (average 1.57 wt.\%), 2.55 3.36 wt. $\% \mathrm{Na}_{2} \mathrm{O}$ (average 2.90 wt. $\%$ ), 0.16 0.43 wt.\% $\mathrm{P}_{2} \mathrm{O}_{5}$ (average 0.33 wt.\%), 3.68 4.01 wt.\% $\mathrm{TiO}_{2}$ (average $3.82 \mathrm{wt} . \%$ ), 9.42 13.06 wt.\% $\mathrm{FeO}$ (average 10.51 wt.\%) and 4.17 6.12 wt.\% $\mathrm{MgO}$ (average 5.11 wt.\%) with high $\mathrm{Na}_{2} \mathrm{O} / \mathrm{K}_{2} \mathrm{O}$ (1.88 on average) and $\mathrm{FeO} / \mathrm{MgO}$ (2.10 on average) ratios, and low $\mathrm{Mg}^{\#}$ values of $0.40 \sim 0.52$ ( 0.46 on average). Samples of Cuiyi diabase contain relatively lower $\mathrm{SiO}_{2}$ (46.95 48.63 wt.\%, $47.96 \mathrm{wt} . \%$ on average), $\mathrm{K}_{2} \mathrm{O}$ of $0.68 \sim 1.42$ wt.\% (average 1.14 wt.\%), $\mathrm{TiO}_{2}$ of 2.56 2.79 wt.\% (average 2.64 wt.\%), $\mathrm{FeO}$ of 7.81 9.27 wt.\% (average 8.46 wt.\%), and higher $\mathrm{Na}_{2} \mathrm{O}$ of $2.97 \sim 3.60 \mathrm{wt} . \%$ (average 3.23 wt.\%), $\mathrm{P}_{2} \mathrm{O}_{5}$ of $0.13 \sim 0.56 \mathrm{wt} . \%$ (average $0.34 \mathrm{wt} . \%$ ), and slightly high $\mathrm{Na}_{2} \mathrm{O} / \mathrm{K}_{2} \mathrm{O}$ (3.03 on average) and $\mathrm{FeO} / \mathrm{MgO}$ (1.48 on average) ratios, $\mathrm{MgO}$ of 5.16 6.34 wt.\% (average $5.78 \mathrm{wt} . \%$ ) and $\mathrm{Mg}^{\#}$ values of $0.50 \sim 0.57$ (average 0.55 ) than Luoji diabase samples.

In the $\mathrm{SiO}_{2}$ vs. $\mathrm{K}_{2} \mathrm{O}+\mathrm{Na}_{2} \mathrm{O}$ diagram (Fig. 4a), all samples plot in the basalt field and are distributed along the line of the alkaline-subalkaline series. They are calc-alkaline to high-K calcalkaline in composition (Fig. 4b) and belong to tholeiite types (Fig. 4c). The high $\mathrm{P}_{2} \mathrm{O}_{5}$ contents of the Luoji and Cuiyi diabases indicate their magma may originate from an enriched mantle (CAMPBELL \& GRIFFITHS, 1993).

\subsection{Rare earth elements}

Rare earth element compositions of the samples in the study are shown in Table 3. Total REE values of the diabase samples range from $163.65 \mathrm{ppm}$ to $301.07 \mathrm{ppm}$ (average $219.90 \mathrm{ppm}$ ) with LREE/ HREE ratios of 6.69 9.52. These samples are enriched in LREE and show high LREE/HREE fractionation $((\mathrm{La} / \mathrm{Yb})$ ${ }_{N}=11.05 \sim 12.29$, Fig. 5a). The normalized REE distribution patterns are similar to the CRB (CUI et al., 2015). The samples show negligible negative to slight positive $\mathrm{Eu}$ anomalies $(\delta \mathrm{Eu}=0.93 \sim 1.06)$, suggesting the existence of pyroxene fractional crystallization (SUN \& MCDONOUGH, 1989; WEAVER, 1991; MIDDLEMOST, 1994).

\subsection{Trace elements}

The trace element results are shown in Table 4. On the primitive mantle-normalized diagram (Fig. 5b), the samples show enrichment in the large ion lithophile elements (LILEs) of $\mathrm{Rb}, \mathrm{Ba}$ and $\mathrm{K}$ and high field strength elements (HFSEs) of Th, Ta and Ti, and depletion in $\mathrm{Sr}, \mathrm{U}, \mathrm{Nb}, \mathrm{P}$ and $\mathrm{Zr}$. The reason for a slight depletion in $\mathrm{K}$ in all samples relative to $\mathrm{Ba}$ and $\mathrm{Rb}$ is that $\mathrm{Ba}$ and $\mathrm{Rb}$ are prone to enter into K-bearing phases during the processes of magmatic fractional crystallization and differentiation (FREY et al., 1978; SZABÓ et al., 2016). The ratios of $\mathrm{Zr} / \mathrm{Nb}(5.76 \sim 6.23), \mathrm{La} /$ $\mathrm{Nb}(0.95 \sim 1.00), \mathrm{Th} / \mathrm{Nb}(0.11 \sim 0.13)$ and $\mathrm{K} / \mathrm{Nb}(255.51 \sim 334.98)$ in the Luoji and Cuiyi diabases are similar to the CRB but are distinct from the OIB (Fig. 5b).

\section{DISCUSSION}

\subsection{Special tectonic setting of the Continental Rift Basalt (CRB)}

Based on tectonic settings, basalts can be divided into three types: Continental Flood Basalts (CFB), Mid-Ocean Ridge Basalts (MORB), and Ocean Island Basalt (OIB) (GREENOUGH \& MCDIVITT, 2018). Different tectonic settings will produce diabases with distinct characteristics. Hence, we can identify and discuss the environment in which diabase occurred with these unique characteristics. Major element contents of all samples are 


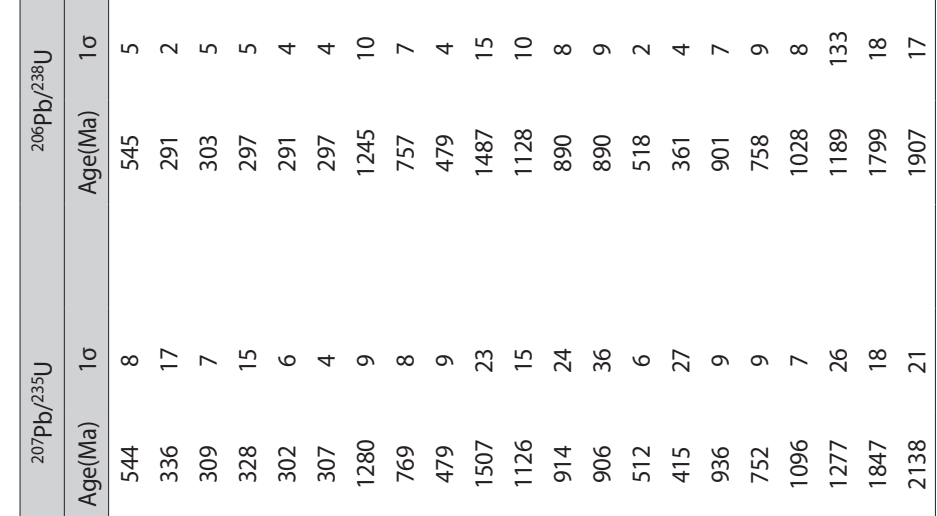

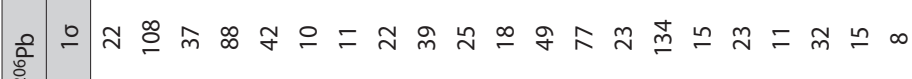
商

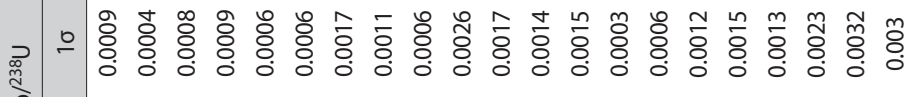

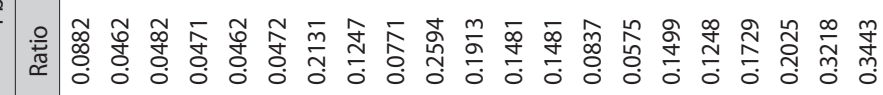

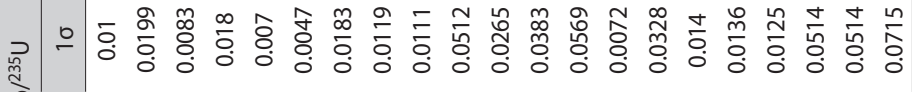

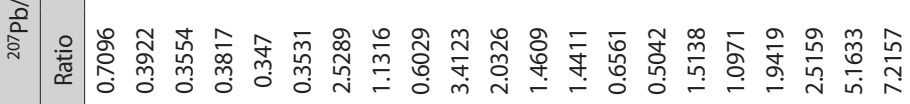

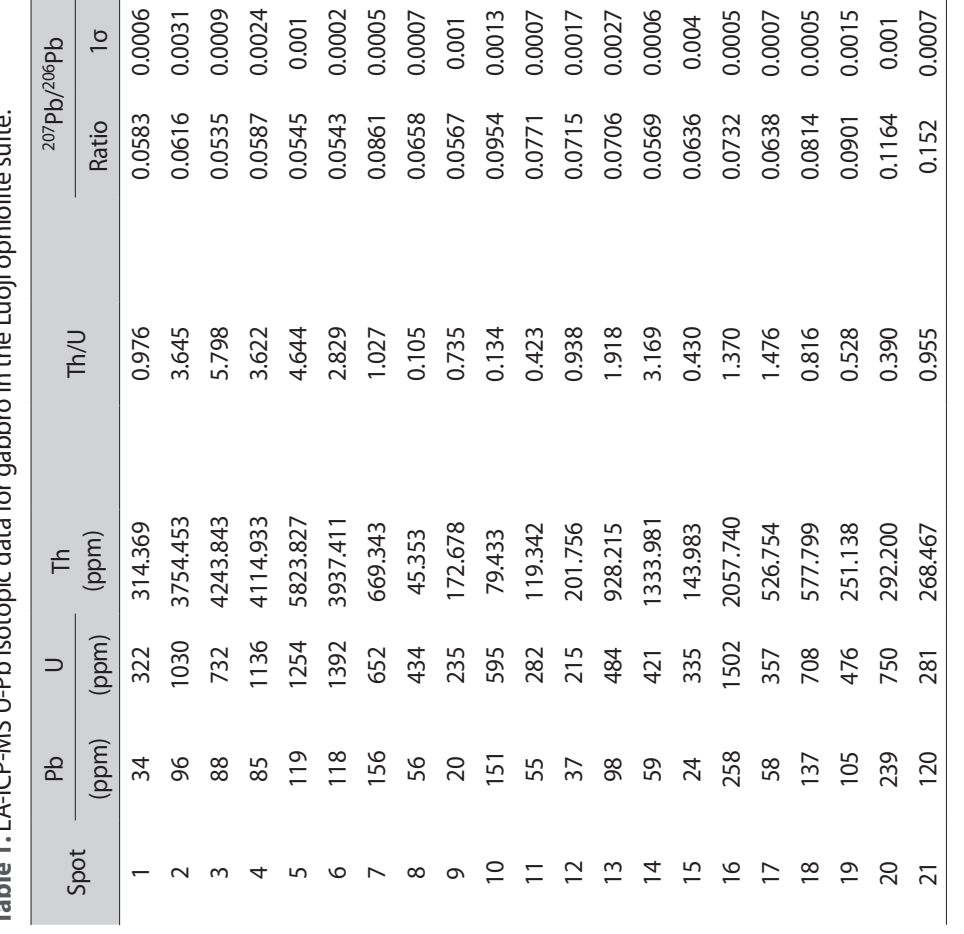

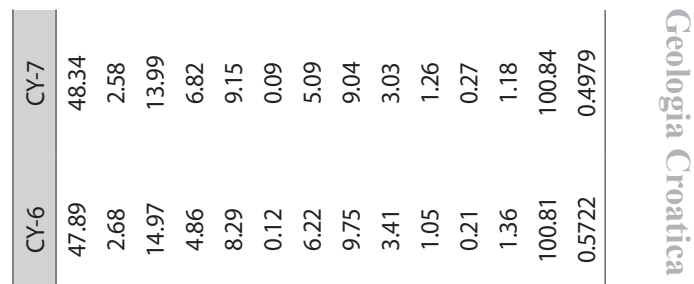

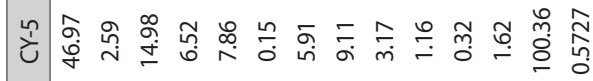

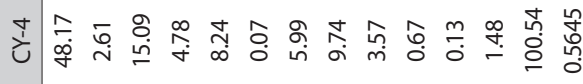

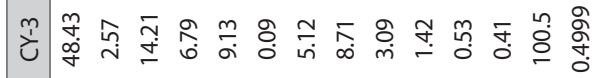

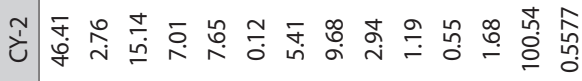

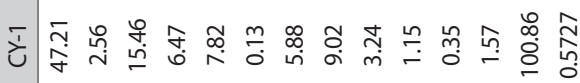

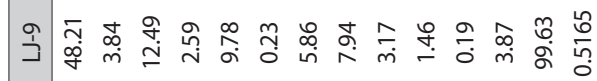

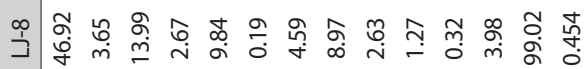

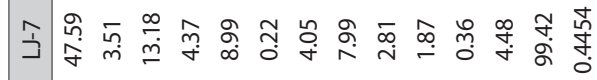

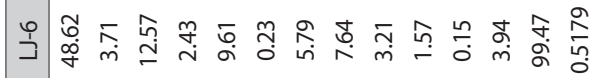

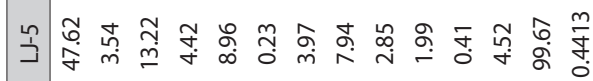

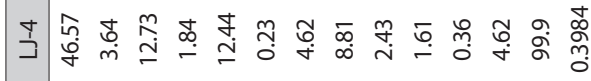

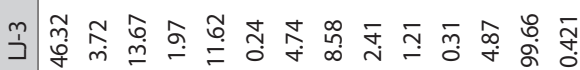

\永

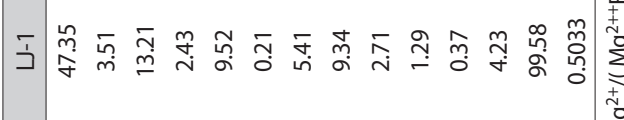

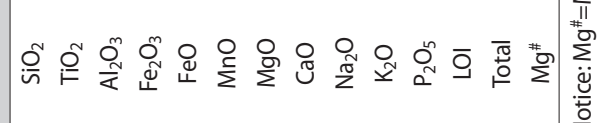




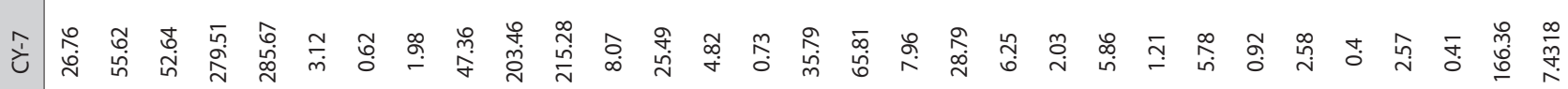

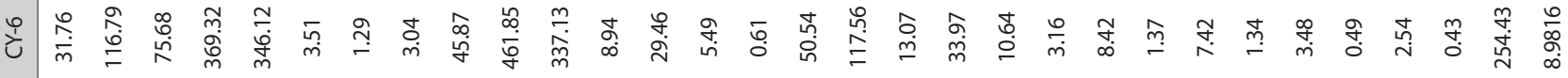

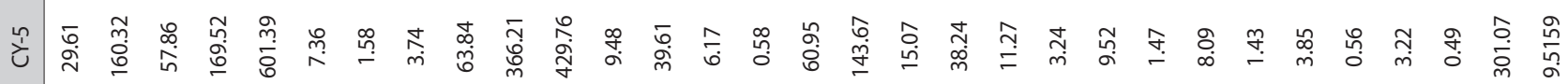

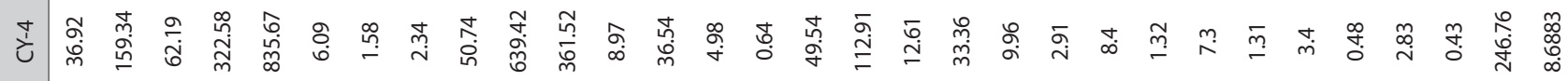

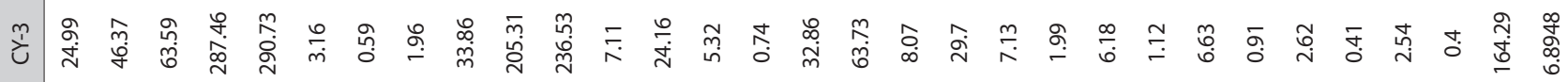

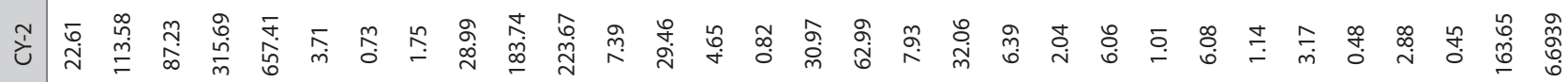

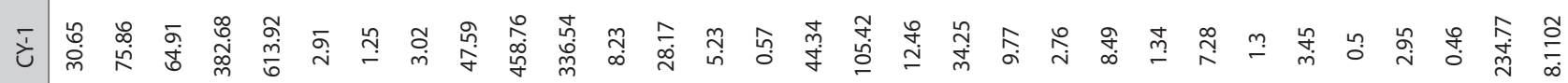

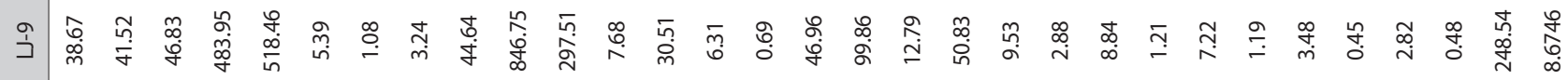

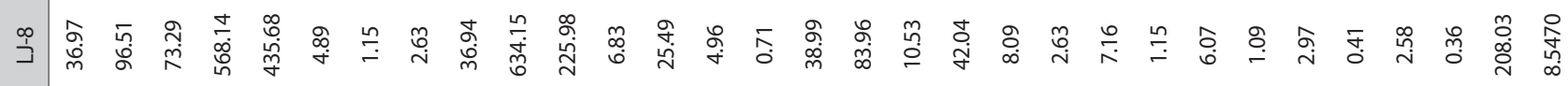

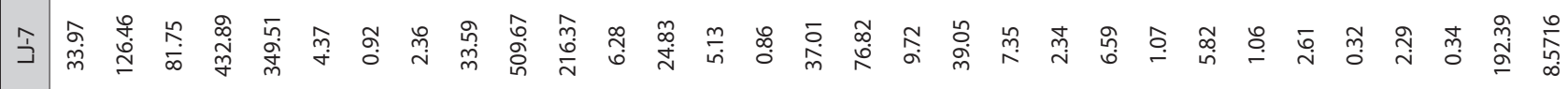

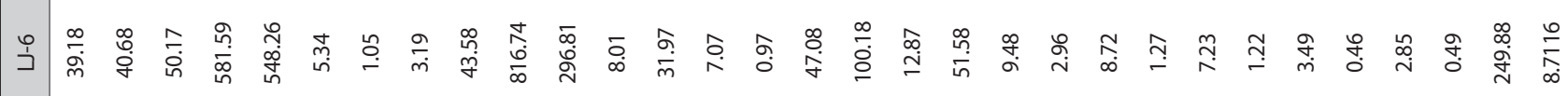

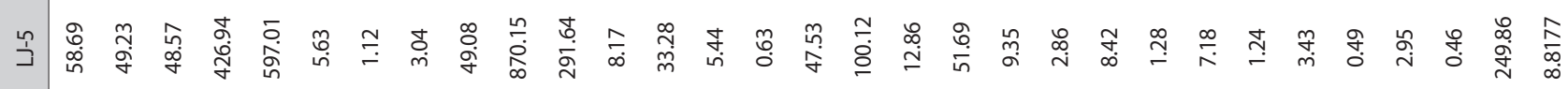

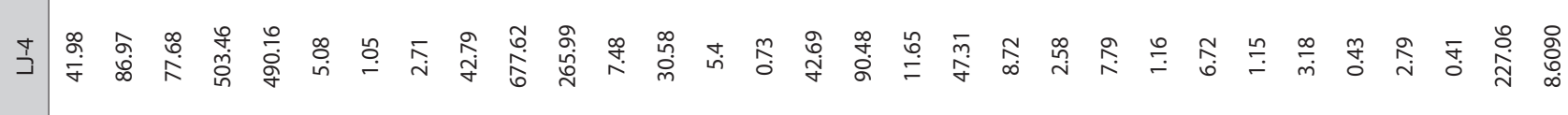

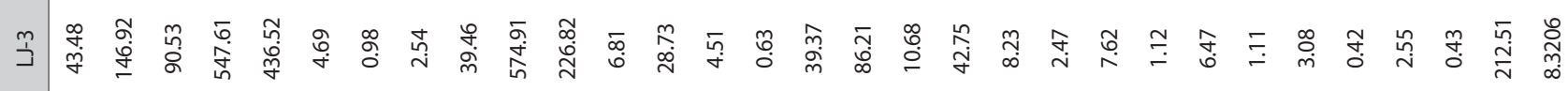

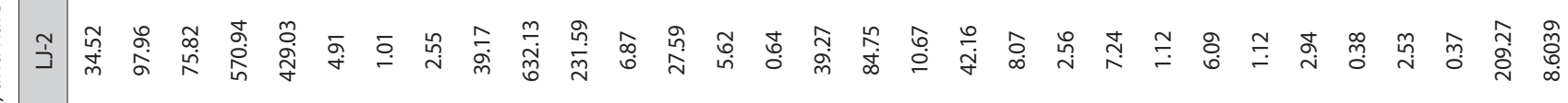

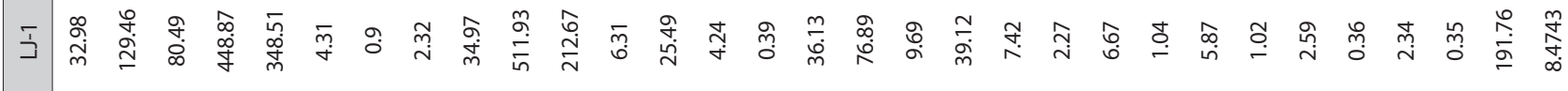

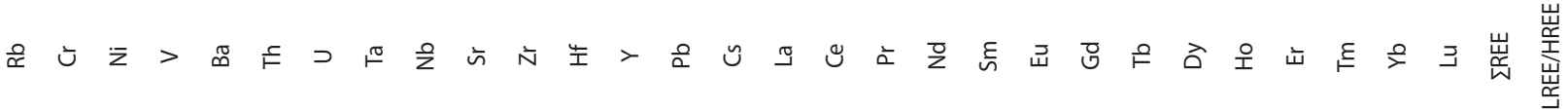



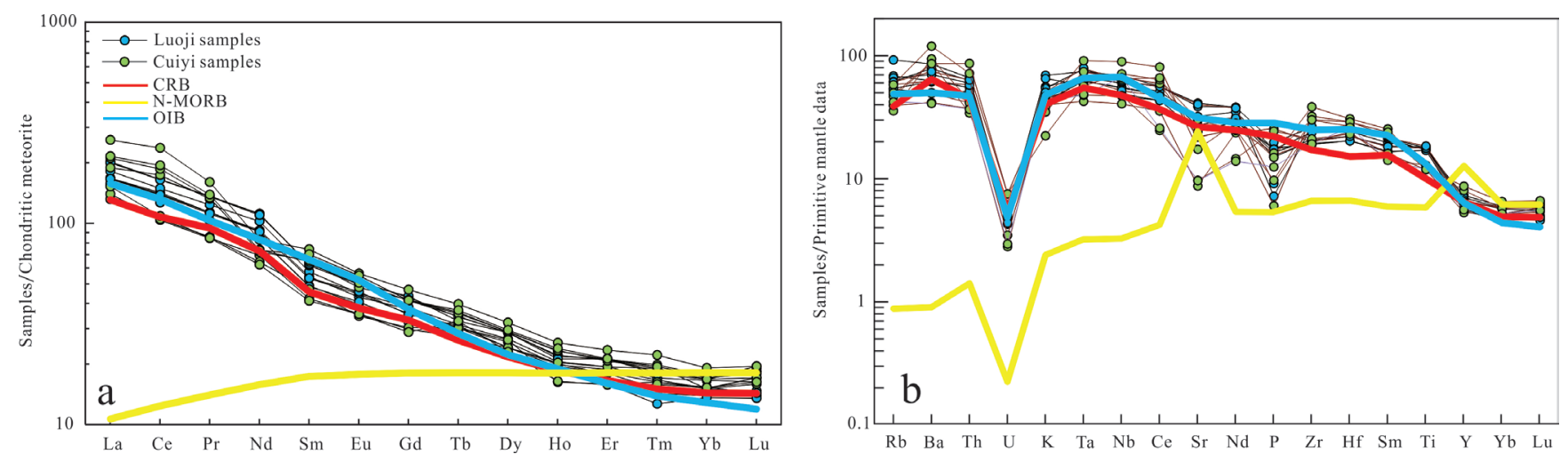

Figure 5. (a) Chondrite-normalized REE distribution pattern and (b) primitive mantle-normalized spider diagram for the samples (after SUN and MCDONOUGH, 1989).
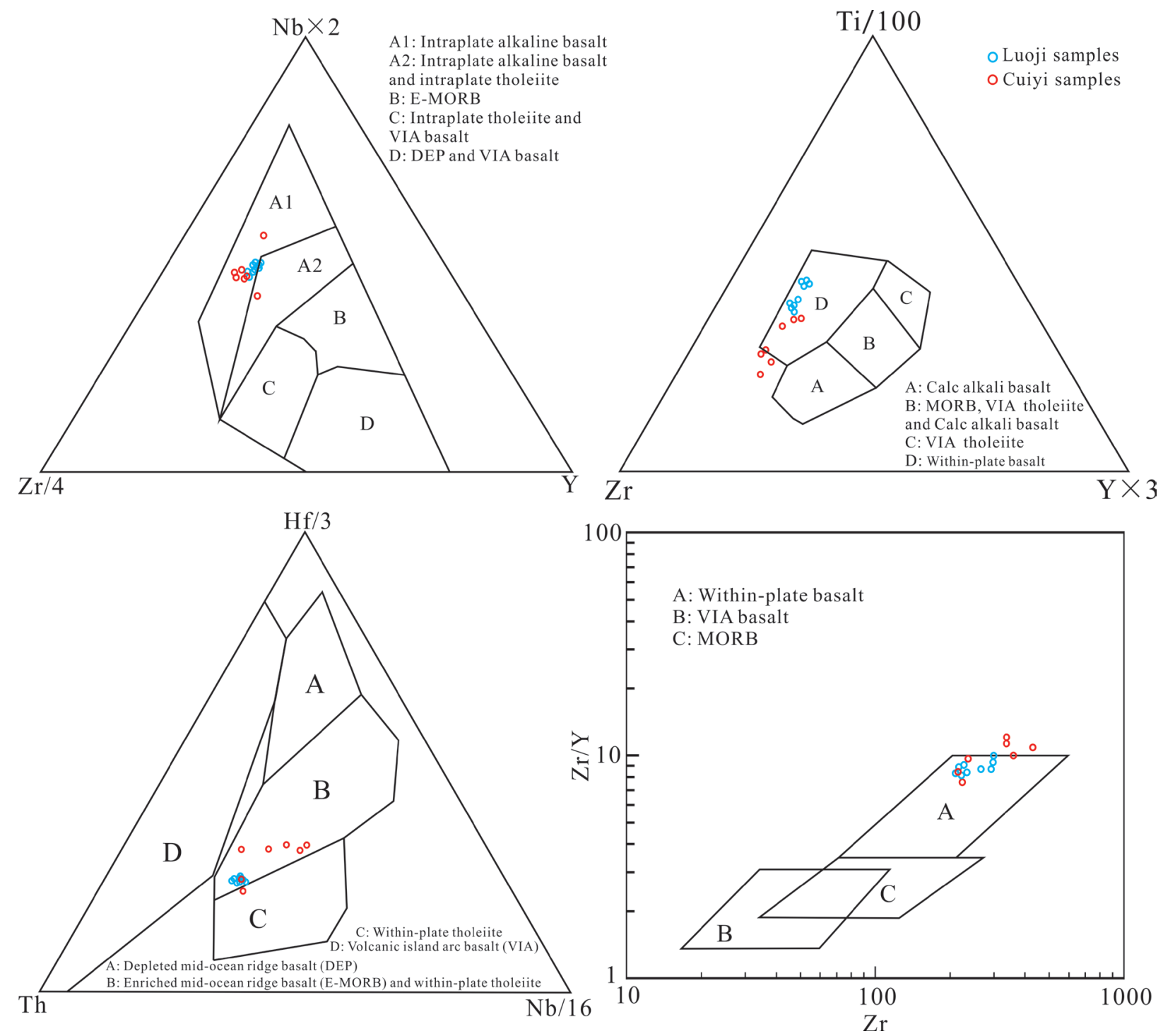

Figure 6. Plots of discrimination diagrams of (a) Zr/4-Nb×2-Y diagram (after MESCHEDE, 1986), (b) Zr-Ti/100-Y×3 diagram (after PEARCE \& CANN, 1973), (c) Th-Hf/3$\mathrm{Nb} / 16$ diagram (after WOOD, 1980) and (d) Zr-Zr/Y diagram (after PEARCE \& NORRY, 1979).

similar to the global mean values of $\mathrm{CRB}$, and they have high contents of continental crust enriched elements of $\mathrm{Cs}$ $(0.39 \sim 0.97 \mathrm{ppm})$ and $\mathrm{Pb}(4.24 \sim 7.07 \mathrm{ppm})$, which is different from N-MORB, E-MORB and OIB, so the studied samples belong to CRB (MACDONALD, 2001; MA et al., 2017). The listric-shaped chondrite-normalized REE patterns of the studied samples are also similar to CRB, but are different from N-MORB and OIB
(Fig. 5a). In addition, the REE diagram for the samples shows LREEs enrichment with obvious HREEs fractionation so that the REE curve trends are different from N-MORB but similar to OIB and CRB (Fig. 5b). However, the slight increase in $\mathrm{Ba}, \mathrm{Yb}$ and $\mathrm{Lu}$, and the relative decline of $\mathrm{Sr}$ and $\mathrm{P}$ are more similar to $\mathrm{CRB}$ rather than OIB. A primitive mantle-normalized spider diagram (Fig. 5b) for samples shows obvious enrichment in LILEs (e.g., 

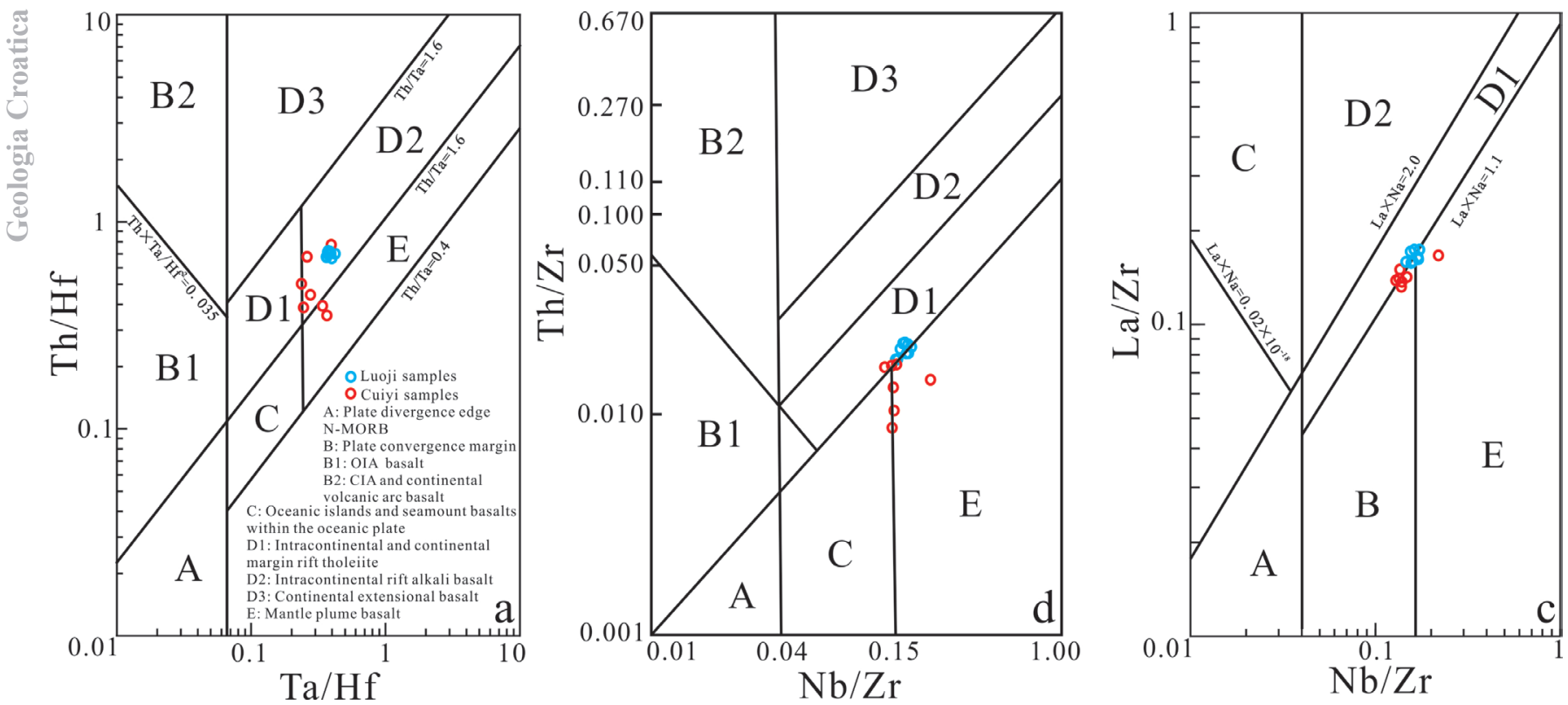

Figure 7. Tectonic setting discrimination diagrams. (a) Ta/Hf vs. Th/Hf diagram (after WANG et al., 2001); (b) Nb/Zr vs. Th/Zr diagram (after SUN et al., 2003); (c) $\mathrm{Nb} / \mathrm{Zr}$ vs. La/Zr diagram (after WU et al., 2003).

$\mathrm{Rb}, \mathrm{Ba}, \mathrm{K})$ and depletion in HFSEs (e.g., U, Nb, Ce), consistent with CRB.

The HFSEs (such as Ta, Nb, Ti, Zr, Hf, Th and Y) and HREE in the basic rocks are usually not affected by metamorphism and hydrothermal alteration under the amphibolite phases (PEARCE et al., 1973). HFSEs are an effective tracer for distinguishing different tectonic settings and magma source regions (FREY et al., 1978; CAMPBELL \& GRIFFITHS, 1993; KHOSHNOODI et al., 2017). According to the tectonic-setting discriminant diagrams of WANG et al. (2002) for basalts, the Th/Ta ratios can be used to distinguish between continent rift and oceanic settings. Luoji diabase samples have lower Hf/Th ratios (1.40 2.82, average $1.75)$, higher $\mathrm{Th} / \mathrm{Ta}(0.96 \sim 2.60$, average 1.78$)$ and $\mathrm{Ta} / \mathrm{Hf}$ $(0.24 \sim 0.42$, average 0.35$)$ ratios than continental within-plate basalt $(\mathrm{Hf} / \mathrm{Th}=8, \mathrm{Th} / \mathrm{Ta}=1.60, \mathrm{Ta} / \mathrm{Hf}=0.1)$, but similar to alkaline basalt $(\mathrm{Ta} / \mathrm{Hf}$ ratios $>0.3)$. All analyzed geochemistry data display within-plate alkaline basalt characteristics, which are consistent with the characteristics of an intracontinental rift basalt. Further, the diabase samples have characteristics of within-plate alkaline basalt and tholeiite from the discrimination diagrams (Fig. 6). In

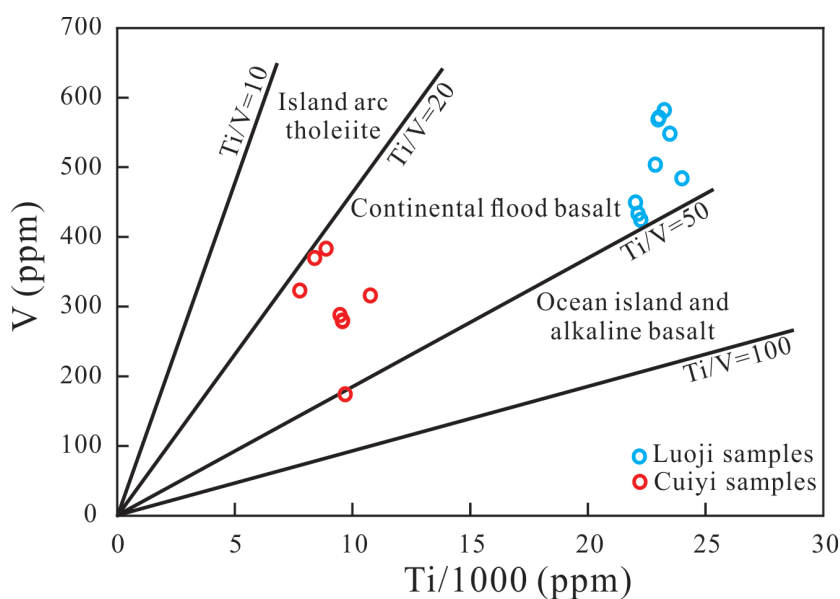

Figure 8. Classification diagram of Ti/1000 vs. V for basaltic magma (after SHERVAIS, 1982). generally, the combination of tholeiite and alkaline basalt series originated from intracontinental rift, initial ocean basin or an ocean island environment (LASSITER \& DEPAOLO, 1997; KISS et al., 2016). Furthermore, all data fall into the intracontinental and continental margin rift tholeiite-alkaline basaltic field (Fig. 7). A small number of Cuiyi diabase samples, which plot in the mantle plume field, may indicate that the continental rift magmatism could have been caused by an active mantle plume/an active mantle mechanism (STOREY \& KYLE, 1997). The diabases belong to high-Ti tholeiite to high-K calc-alkaline series with depletion in some HFSEs, which is also similar to CRB (MAHONEY et al., 1995; MACDONALD et al., 2001). All samples fall into the CFB field (Fig. 8), which also shows that the Luoji and Cuiyi diabases are mainly within-plate basalts during the continental rift formation period.

\subsection{Magma characteristics of the rocks \\ 5.2.1. Source region}

In this study, HFSEs and REEs can be good indicators for source regions. In Fig. 9 and Fig. 10a, the samples all originated from a low-degree partial melting of enriched mantle with the participation of a small quantity of crust and/or continental margin material, which is highly consistent with CRB (CAMPBELL \& GRIFFITHS, 1993; LASSITER \& DEPAOLO, 1997). This suggests that the magma source region may have a slight crustal contamination (PECCERILLO \& TAYLOR, 1976), and all samples fall into the $\mathrm{CRB}$ field in the $\mathrm{La} / \mathrm{Nb}$ vs. $\mathrm{La} / \mathrm{Ba}$ discrimination diagrams (Fig. 10b), which also indicates a slight crustal contamination (CUI et al., 2015).

High $\mathrm{Ce} / \mathrm{Yb}$ ratios of the diabases $(32.58 \sim 33.78)$ indicate the low-degree of melting and garnets as the main residual phases, and the samples also plot in the garnet stable field (Fig. 11a, CUI et al., 2015; KISS et al., 2016). In the La/Sm vs. Sm/Yb diagram (Fig. 12a), the samples all plot on the upper part of the primitive mantle melting curve with a slight deviation from the melting of the garnet lherzolite field, which may be caused by the low-degree melting of the source region and a certain degree of upper crustal contamination (CAMPBELL \& GRIFFITHS, 1993; MA- 

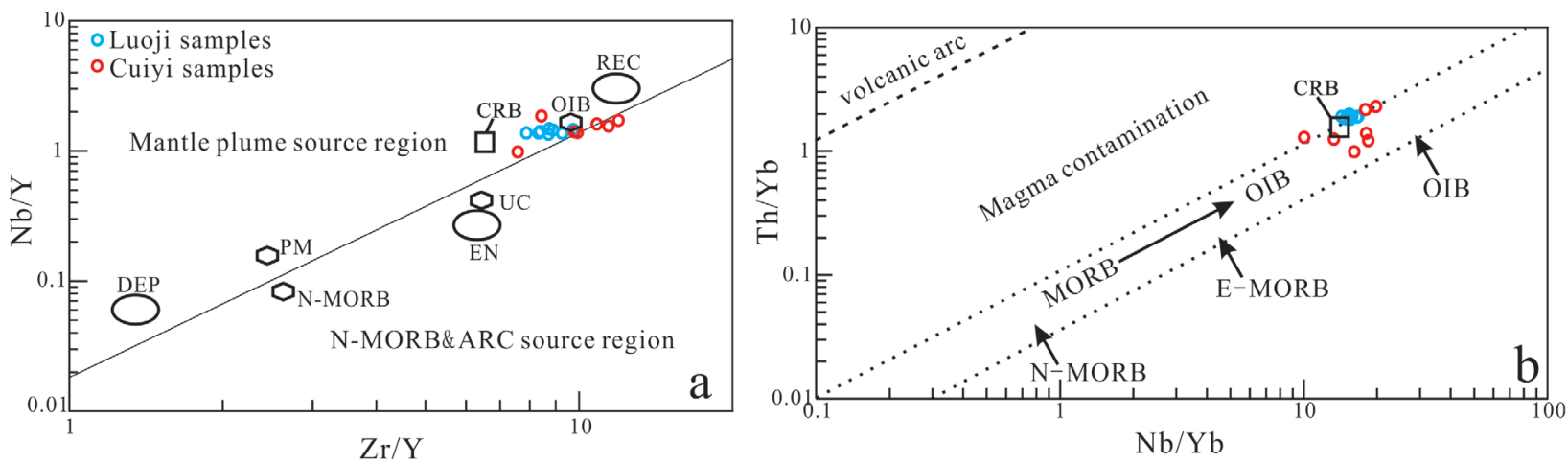

DEP: Depleted mantle; REC: Recycling plant composition

EN: Enriched mantle; PM: Primitive mantle

N-MORB: Normal mid-ocean ridge basalt; OIB: Ocean island basalt UC: Upper crust; ARC: Island arc magma
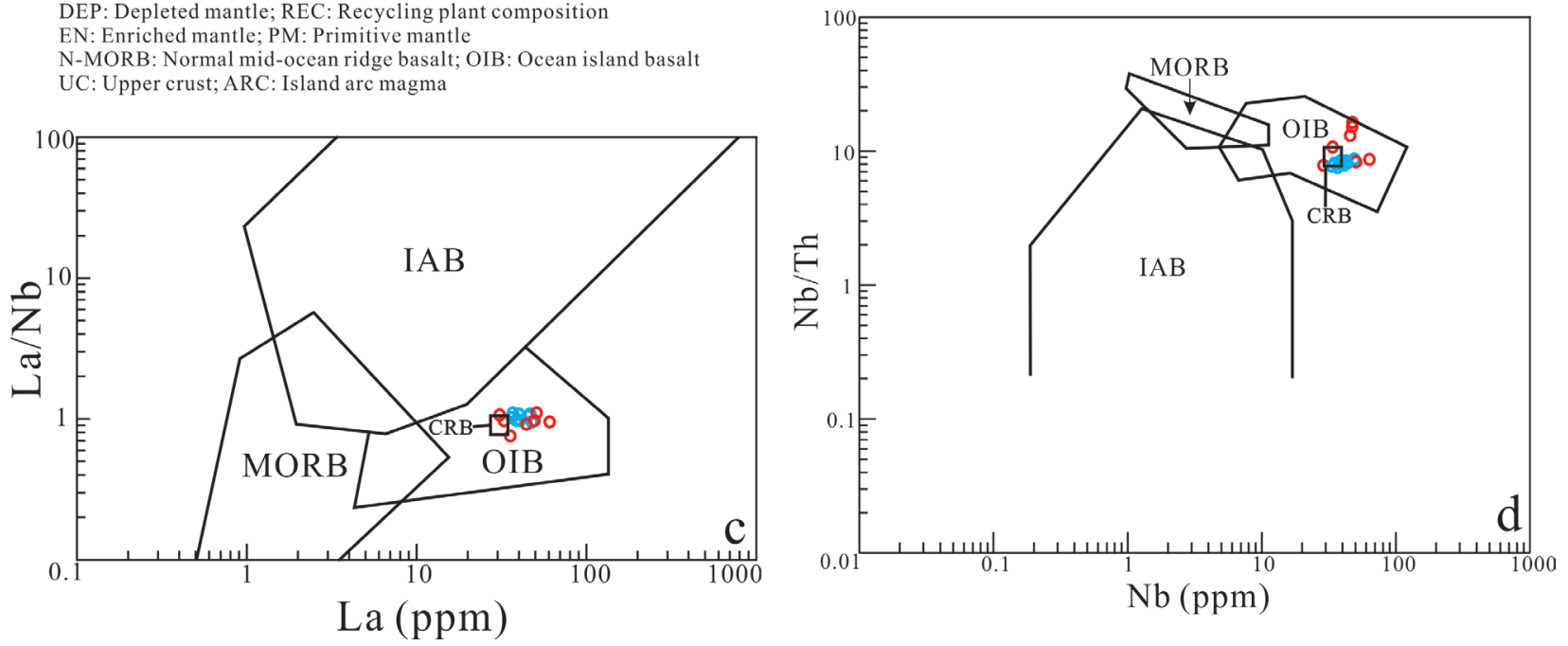

Figure 9. Source discrimination diagrams. (a) Zr/Y vs. Nb/Y diagram (after SAUNDERS et al., 1997); (b) Nb/Yb vs. Th/Yb diagram (after PEARCE, 1982); (c) La vs. La/Nb diagram (after LI, 1993); (d) Nb vs. Nb/Th diagram (after LI, 1993).

HONEY et al., 1995; JUNG \& MASBERG, 1998). Further, the samples plot near the primary garnet lherzolite field and the distribution of the Luoji diabase samples is relatively concentrated (Fig. 12b), which indicate the samples may be the products of partial melting of $2 \% \sim 3 \%$ garnet lherzolite phases (KHOSHNOODI et al., 2017; MA et al., 2017). Although the distribution of the Cuiyi diabase samples is relatively wide (Fig. 12b), it is still in the vicinity of the primary garnet lherzolite field. The reason why the $\mathrm{Ce} / \mathrm{Y}$ ratios of the Cuiyi diabase fluctuates greatly may be caused by crustal contamination. Combined with the Hf vs. $\mathrm{Hf} / \mathrm{Yb}$ diagram (Fig. 11b), it shows that diabases originated in a deep position and were formed by decompression melting of the mantle with a low degree of partial melting and strong differentiation of LREE and HREE (especially in the Cuiyi diabase). There is an obvious negative $\mathrm{P}$ anomaly in all samples without extreme deficiency in the chondrite-normalized REE distribution pattern (Fig. 5a), which can be combined with three possible reasons for negative P anomalies (CAMPBELL \& GRIFFITHS, 1993; KISS et al., 2016): a source region deficiency in P; residual apatites in the source region; fractional crystallization of negative $\mathrm{P}$ minerals, where apatites remained in the source region resulting in less $\mathrm{P}$ in samples than in the global CRB-type samples.
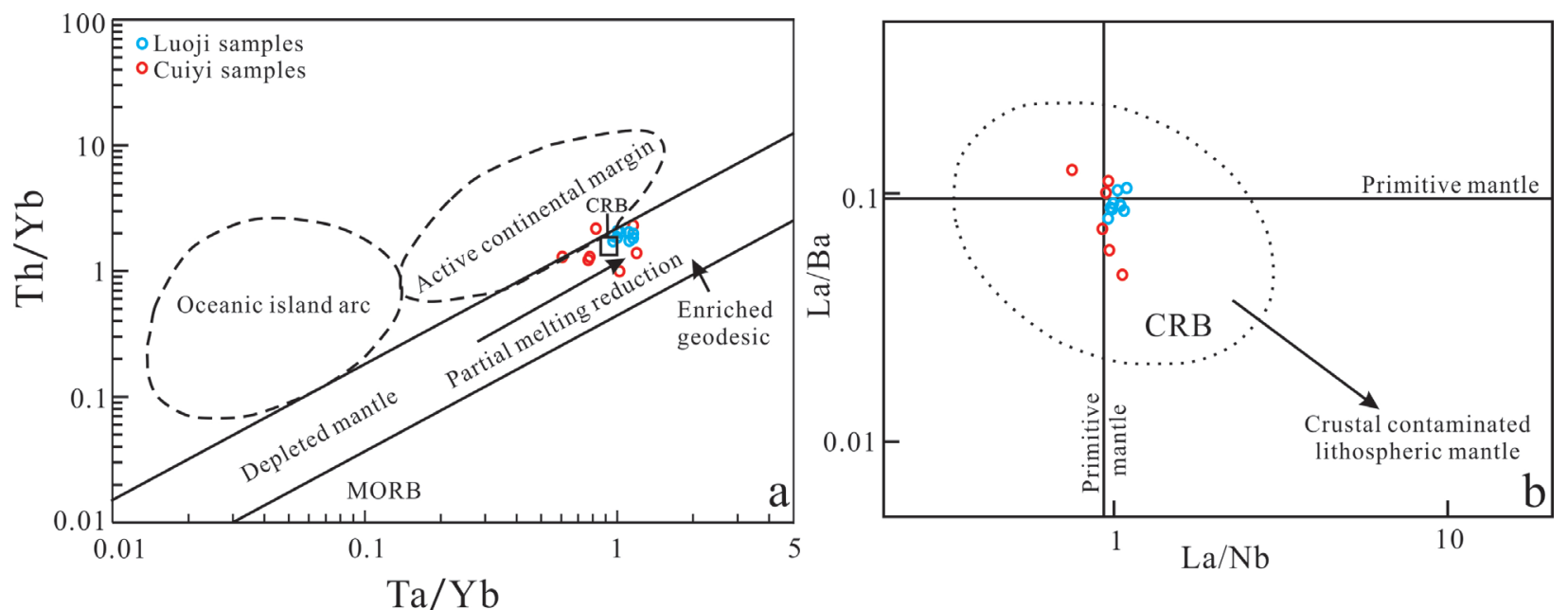

Figure 10. (a) Ta/Yb vs. Th/Yb diagram (after PEARCE, 1982); (b) La/Nb vs. La/Ba diagram for crustal contamination (after MILLER et al., 1999). 

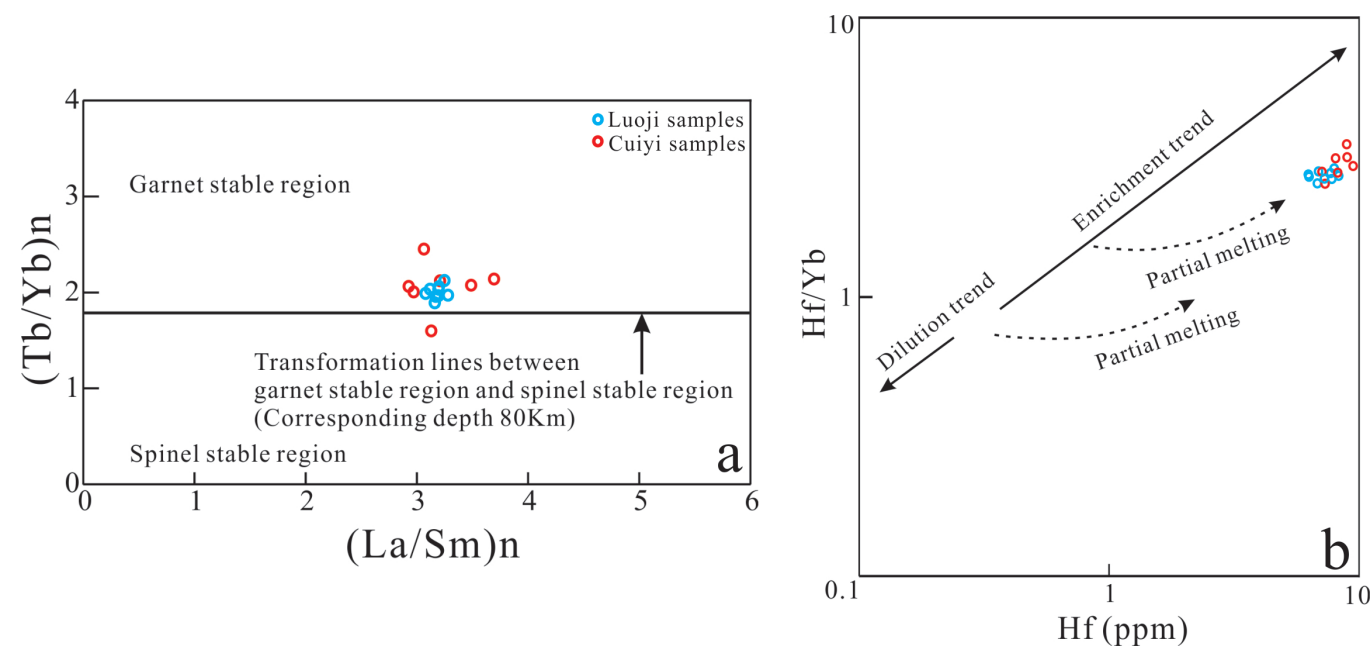

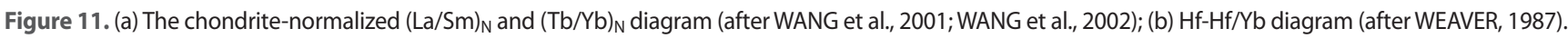
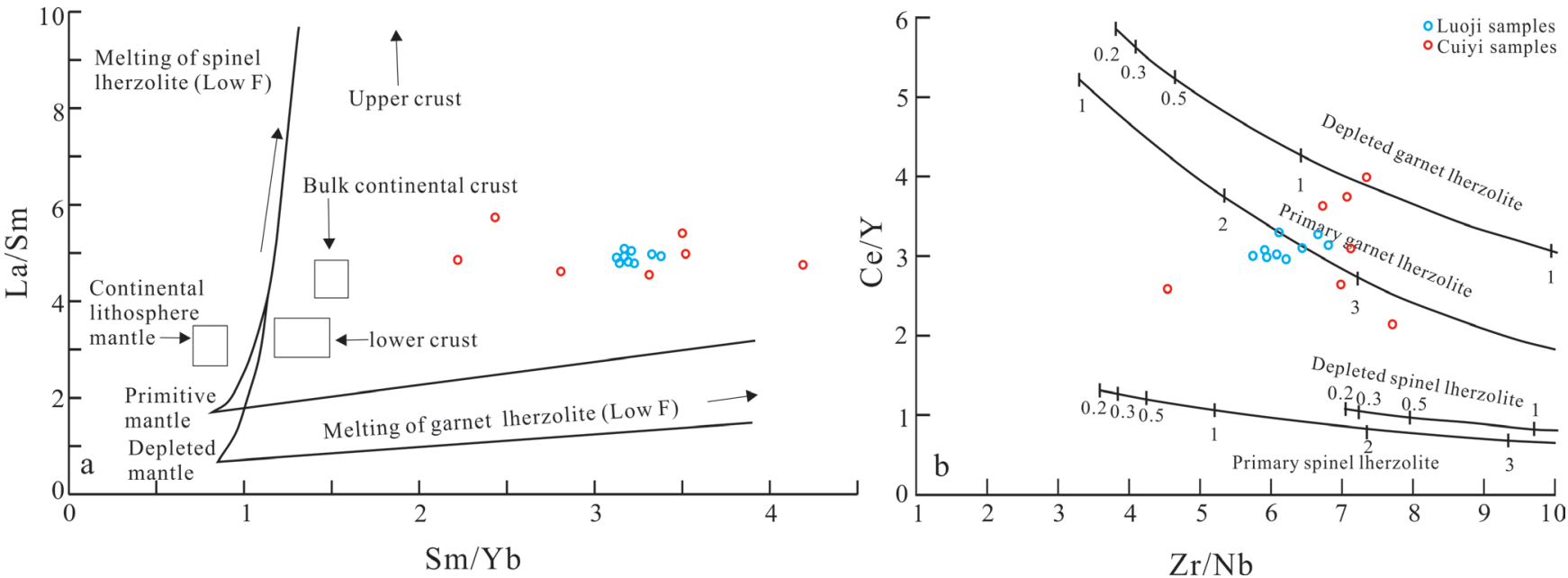

Figure 12. (a) La/Sm vs. Sm/Yb diagram (after LASSITER \& DEPAOLO, 1997); (b) Zr/Nb vs. Ce/Y diagram (after GAO et al., 2009).

\subsubsection{Assimilation and Contamination}

The $\mathrm{Mg}^{\#}$ values of the samples vary from 0.40 to 0.57 and are significantly lower than those of the primary magma $(0.68 \sim 0.75)$, which indicates that the rocks had experienced a certain degree of fractional crystallization (FREY et al., 1978). Low contents of $\mathrm{MgO}$ and $\mathrm{FeO}$ in the samples may indicate the fractional crystallization of augite and diopside during the process of magmatic evolution, or the formation of a basic-ultrabasic complex (cumulates), which results in a large reduction of Mg (HAWKESWORTH et al., 1993; JUNG \& MASBERG, 1998; KHOSHNOODI et al., 2017), and then the magmatic differentiation formed the geochemical characteristics of low Mg in the diabases.

According to the compatibility of elements in different minerals, the abundance of elements will change with crystallization. The ratios of elements sensitive to assimilation and contamination are an indicator of assimilation and contamination because of the compositional differences between the crust and the mantle (CAMBELL \& GRIFFITHS, 1993; MACDONALD et al, 2001). The Luoji and Cuiyi diabases show an obvious positive correlation in the $\mathrm{Th} / \mathrm{Nb}$ vs. $\mathrm{Ce} / \mathrm{Nb}$ and $\mathrm{Ta} / \mathrm{Yb}$ vs. $\mathrm{Th} / \mathrm{Yb}$ diagrams (Fig. 13a and 13b), indicating that there is a certain assimilation and contamination in the samples (HAWKESWORTH et al., 1993; KISS et al., 2016). The $\mathrm{Nb} / \mathrm{U}$ and $\mathrm{Ta} / \mathrm{U}$ ratios of the samples are 32.12 76.39 (average 42.10) and 1.48 3.32 (average
2.59), respectively, which are lower than the global relative homogeneous values of MORB and $\mathrm{OIB}(\mathrm{Nb} / \mathrm{U} \approx 47$ and $\mathrm{Ta} / \mathrm{U} \approx 2.7)$. The Ta/La ratios $(0.05 \sim 0.07$, average 0.062$)$ are slightly higher than the standard value (0.06) of the original mantle (LIANG et al., 2018), which indicate that the diabases are obviously contaminated by the crust or the source region. It is generally believed that the crustal material has low $\mathrm{Nb}$ and high Th characteristics (WANG et al., 2018). The positive correlation between Th and $\mathrm{Nb}$ (Fig. 13c), a slight negative correlation between $\mathrm{La} / \mathrm{Yb}$ and $\mathrm{Nb} / \mathrm{Ta}$ (Fig. 13d) and a slight negative $\mathrm{Nb}$ anomaly in the diabases, together indicate that the samples have been affected by crustal contamination (JUNG \& MASBERG, 1998). Similarly, the depletion in LILE of $\mathrm{Sr}$ in the primitive mantle-normalized spider diagram (Fig. 5b) may be mainly due to the contamination by crustal materials (SZABÓ et al., 2016; KISS et al., 2016).

Variation of mantle element contents and $\mathrm{Nb} / \mathrm{La}$ ratios are an obvious indicator of the process of assimilation, contamination and fractional crystallization (TAYLOR \& MCLENNAN et al., 1995). There is a positive correlation between $\mathrm{Mg \#}$ and $\mathrm{Cr}$, $\mathrm{Ni}, \mathrm{V}, \mathrm{Zr}, \mathrm{Sr}$ and $\mathrm{Nb} / \mathrm{La}$ (Fig. 14), which shows that the fractional crystallization of the diabases are affected by assimilation and contamination (FREY et al., 1978; CAMPBELL \& GRIFFITHS, 1993; HAWKESWORTH et al., 1993). Meanwhile, the $\mathrm{SiO}_{2}$ vs. $\mathrm{Nb}$ /La diagram (Fig. 15a) indicates that the evolutionary process of the diabases is dominated by fractional crystallization, and 

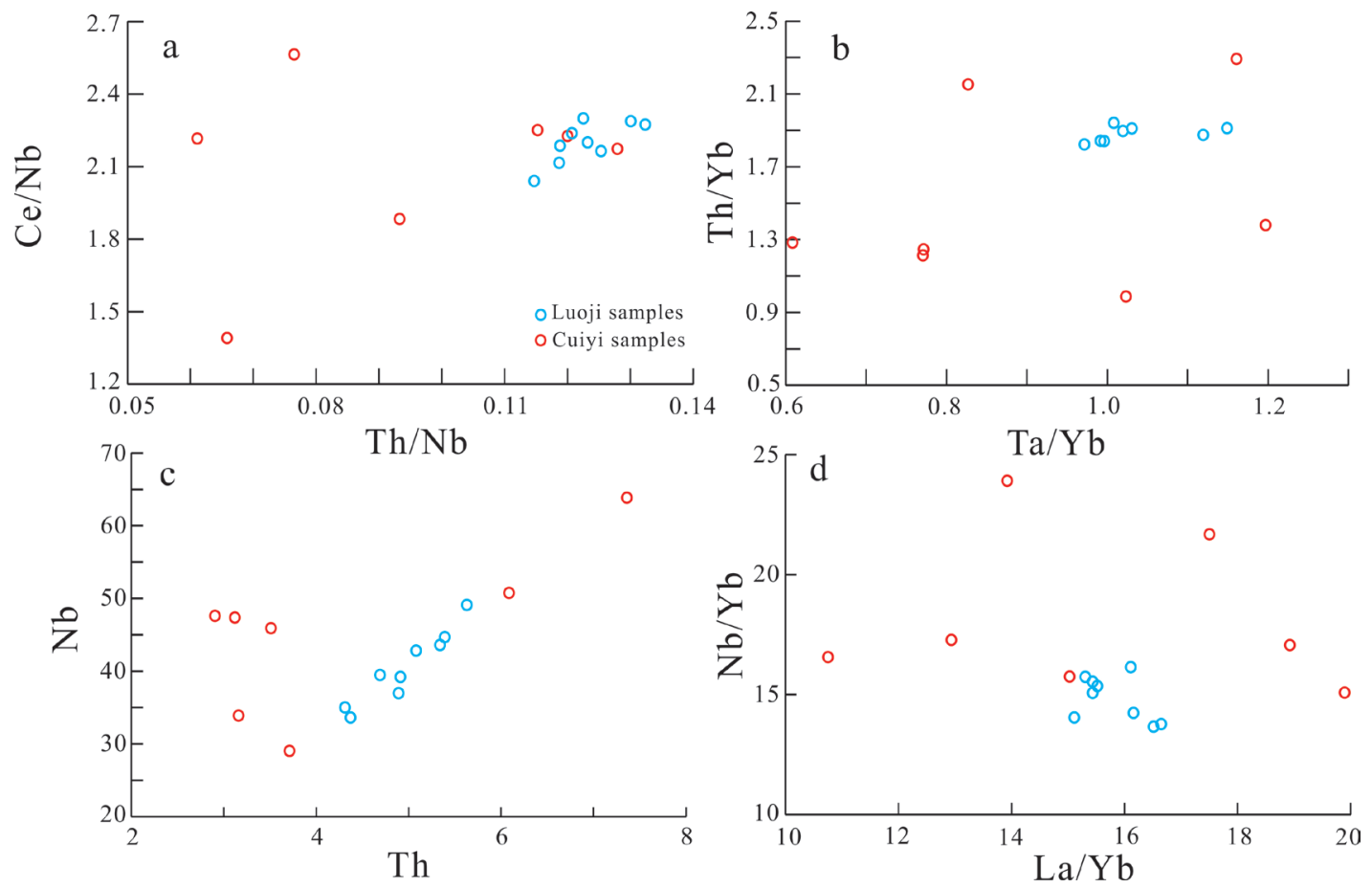

Figure 13. Trace element discrimination diagrams for assimilation and contamination.
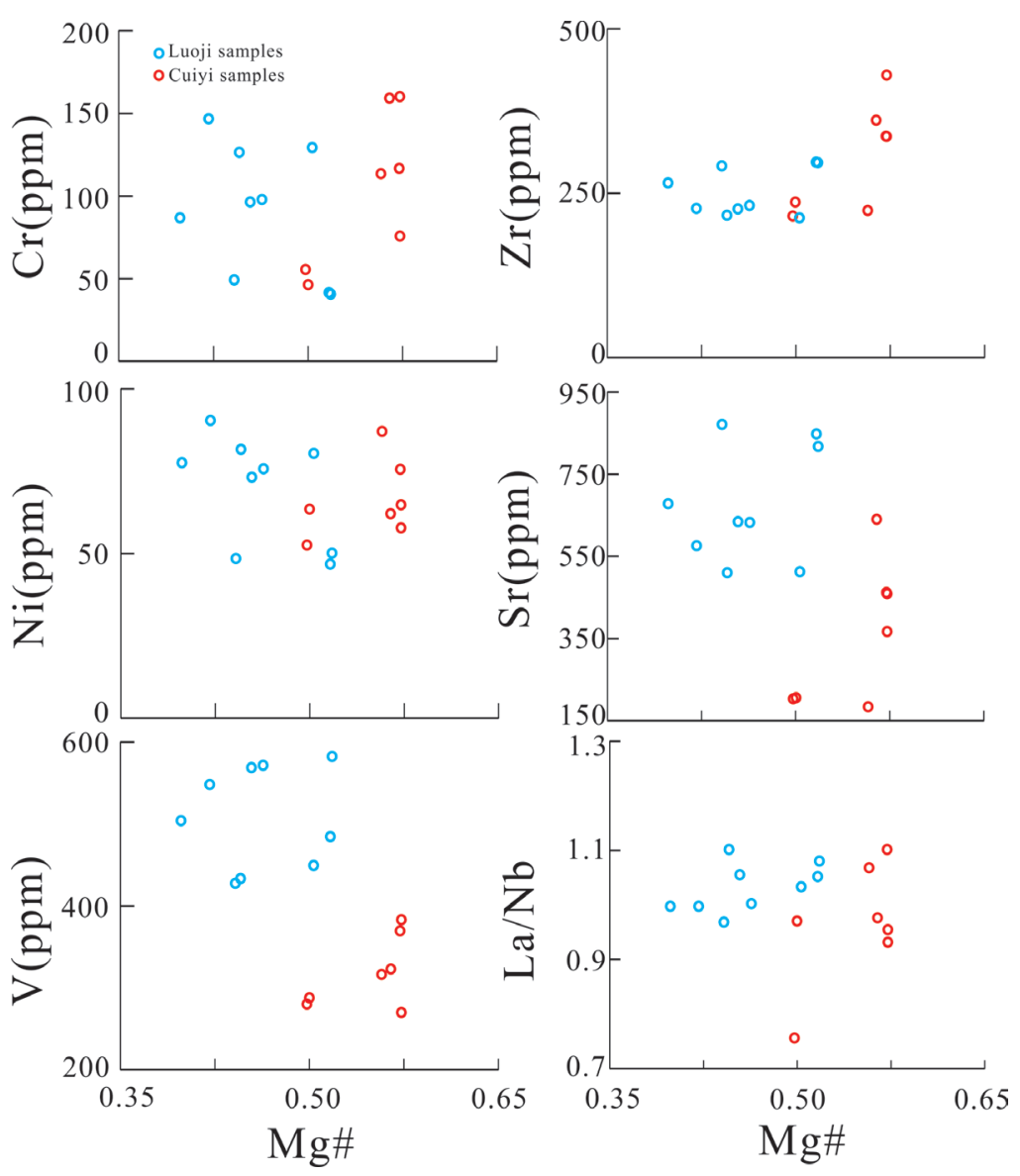

Figure 14. Plots of selected trace elements with Mg\# for discrimination contamination.

there are signs of contemporaneous assimilation and contamination. In the $\mathrm{CaO}$ vs. $\mathrm{CaO} / \mathrm{Al}_{2} \mathrm{O}_{3}$ diagram (Fig. 15b) the two groups of samples are consistent with a large consumption of $\mathrm{Mg}$ in the magma caused by the fractional crystallization with clinopyroxene resulting in the low $\mathrm{MgO}$ content in the samples. The relative enrichments in $\mathrm{Rb}, \mathrm{Ba}$ and Th also indicate that magmatic migration has undergone crustal contamination (CUI et al., 2015; KISS et al., 2016). Previous studies (MACDONALD et al., 2001; MA et al., 2017) have shown that strong depletion in Sr of some highMg basalts may be affected by contamination or alteration. There- 

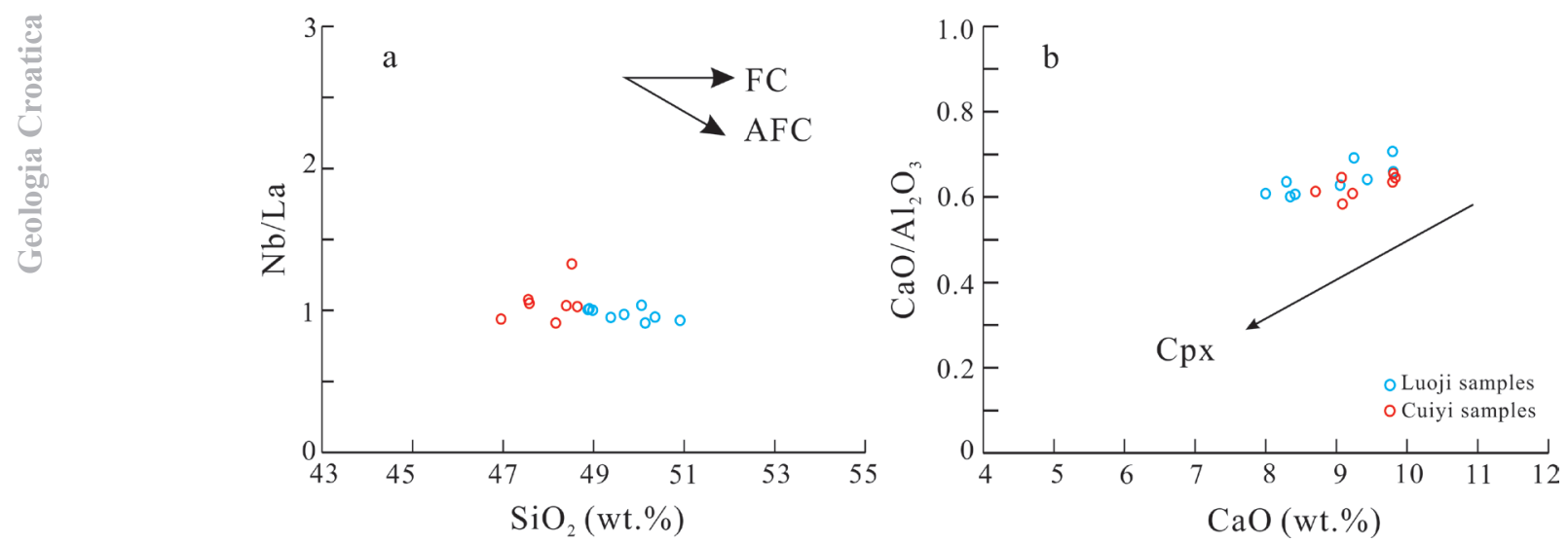

Figure 15. Discrimination diagrams for fractional crystallization and assimilation-contamination. (a) $\mathrm{SiO}_{2}$ vs. Nb/La diagram; (b) $\mathrm{CaO}$ vs. $\mathrm{CaO} / \mathrm{Al}_{2} \mathrm{O}_{3}$ diagram.

fore, negative Sr anomalies and negligible negative Eu anomalies in the samples are not caused by plagioclase fractionation.

Combined with the above analysis, the geochemical characteristics of major and trace elements in the samples may reflect assimilation and contamination by crustal rocks during the emplacement of the CRB magma.

\subsection{Geological significances}

The timing of the opening of the Ganzi-Litang Ocean basin may have been in the Early Carboniferous, subduction in the Early Triassic and closure in the terminal period of the Late Triassic (WANG et al., 2018). Combined with the recent study, it can be concluded that the study area has experienced three tectonic evolutionary stages during the Permian to Triassic period, i.e., an intracontinental rift basin stage during the Early to Middle Permian, initial ocean basin stage during the terminal Permian and oceanic crust subduction stage during the Late Permian to Early Triassic (HOU et al., 2001; LIANG et al., 2018). However, the opening time of the Ganzi-Litang Ocean basin is controversial due to the uncertainty of the stretching time and the complexity of the rock exposures. Hence, the accurate development timing especially of the intracontinental rift stage of initial Ganzi-Litang Ocean has never been reported. All the collected data including the zircon $\mathrm{U}-\mathrm{Pb}$ ages of MORB and OIB, is disadvantageous and incomplete for determining the timing of the opening and the evolutionary processes for the Ganzi-Litang Ocean without the CRB. So a large number of diabase samples were sought in this study to find out the CRB samples. Finally, the Luoji and Cuiyi diabase samples were discovered and have typical CRB characteristics discovered through geochemical data analysis. This indicates that the crystallization age of the Luoji diabase can accurately define the timing of the intracontinental rift stage of the Ganzi-Litang Ocean and is also essential for determining the precise timing of the opening of the Ganzi-Litang Ocean.

In view of the zircon structures and $\mathrm{Th} / \mathrm{U}$ ratios $(0.11 \sim 5.80)$, zircons from the Luoji diabase indicate they are of magmatic origin. A Concordia age of the oldest 21 analyses is $1907 \mathrm{Ma}$, which may represent a mantle-derived magmatic event in the western margin of the Yangtze Block in the late Palaeoproterozoic (ZHAO et al., 2010). A set of data in 1245Ma 1028Ma may represent the Grenvillian orogeny and related magmatic events during the Mesoproterozoic period (LI et al., 2002). Another set of data in 901Ma 757Ma may represent a magmatic event with a span of about 260Ma (1000Ma 740Ma) in the western margin of the Yangtze in the Neoproterozoic (SUN et al., 2009). These zircons would be inherited zircons. For the youngest set of data (303Ma 291Ma), the zircon U-Pb age of the Luoji samples is 293.4 5.4Ma (Early Permian), which should represent the crystallization age of the rock. Some zircon U-Pb ages have been obtained in the southern part of the Ganzi-Litang suture zone. For example, $341.6 \pm 4.9 \mathrm{Ma}$ of mid-ocean ridge low-K tholeiite series gabbro in the ophiolite mélange belt, the Baihanchang area, $272.8 \pm 1.2 \mathrm{Ma}$ for a gabbro-diabase in the Tuguan village and $221.24 \pm 0.93 \mathrm{Ma}$ of the OFB (floor-ocean ridge basalt)-MORB in Tangyang Country. The age of the Hongshan-Shudu ophiolites determined by Sm-Nd isotope is $230 \mathrm{Ma}$ (HOU et al., 2001; YBGMRRGST, 2003; LIANG et al., 2018). In the middle part of the Ganzi-Litang suture zone, an LA-MC-ICP-MS zircon U-Pb age of the pillow basalt in the Charichadong area is $271 \pm 10 \mathrm{Ma}$. In terms of biostratigraphy, the Early Triassic radiolarians were developed in the Litang Wenquan and Early-Late Triassic radiolarians were developed in the Yazui pasture Xigou-Litang Wenquan. In the northern part of the Ganzi-Litang suture zone, the zircon $\mathrm{U}-\mathrm{Pb}$ age of the gabbro in the N-MORB ophiolite is $292 \pm 4 \mathrm{Ma}$. In terms of biostratigraphy, the Early Carboniferous radiolarians in siliceous rocks are developed in the Zhuqing area of northern Ganzi, in addition, Early Carboniferous, Middle Permian, Middle Triassic and Late Triassic radiolarian siliceous rocks occur in the Yushu Xiewu, Dege Country Zhuqinglangduo-Sanchahe and Zhuqing village-Jike (HOU et al., 2001). Based on the zircon U-Pb ages, the Luoji and Cuiyi diabases may belong to the products of the intracontinental rift-initial ocean basin stage.

Combining the data of zircon geochronology and biostratigraphic geochronology from north to south, suggests that there is a trend towards a younging for the timing of the opening of the Ganzi-Litang Ocean from the north to the south, which may be related to the evolution of the Ganzi-Litang Ocean.

The U-Pb age of the intracontinental rift-type diabase in the study area is $293.4 \pm 5.4 \mathrm{Ma}$, which is analogous with the zircon age of the N-MORB ophiolite in the Ganzi area (LIANG et al., 2018). This also shows that the opening of the Ganzi-Litang Ocean in the southern section may have lagged behind that in the northern section. Therefore, the comprehensive analysis shows that the study area started to enter into an intracontinental rift stage of initializing the Ganzi-Litang Ocean at $293.4 \pm 5.4 \mathrm{Ma}$ (Early Permian) and formed an enriched mantle parent magma with CRB affinity. Then the parent magma formed the Luoji diabase in the intracontinental rift environment through crystallization and differentiation, assimilation and contamination and ascending emplacement. 


\section{CONCLUSION}

1. The Luoji and Cuiyi diabases are high-K alkaline to -tholeiite with low Si, high Ti, K, Fe and Zr characteristics, which are similar to CRB but different from N-MORB and OIB.

2. The diabases were formed by low-degree partial melting of an enriched mantle source consisting of garnet lherzolite with slight crustal contamination. They were formed in an intracontinental rift basalt setting, related to mantle plume activity during the initial opening stage of the Ganzi-Litang Ocean.

3. LA-ICP-MS zircon U-Pb data show that the Luoji diabase was emplaced at $293.4 \pm 5.4 \mathrm{Ma}$, indicating the initial opening of the Ganzi-Litang Ocean occurred during the very Early Permian.

\section{REFERENCES}

CAMPBELL, I.H. \& GRIFFITHS, R.W. (1993): The evolution of the mantle's chemical structure-- Lithos, 30, 389-399. doi: 10.1016/0024-4937(93)90047-G

CUI, X.Z., JIANG, X.S., WANG, J., WANG, X.C., ZHOU, J.W., DENG, Q., LIAO, S.Y., WU, H., JIANG, Z.F. \& WEI, Y.N. (2015): Mid-Neoproterozoic diabase dykes from Xide in the western Yangtze Block, South China: New evidence for continental rifting related to the breakup of Rodinia supercontinent.- Precambrian Research, 268, 339-356. Doi: 10.1016/j.precamres.2015.07.017

FREY, F.A., GREEN, D.H. \& ROY, S.D. (1978): Intergrated models of basalts petrogenesis: A study of quartz tholeiites to olivine melitites from southeastern Australia utilizing geochemical and experimental petrological data.- Journal of Petrology, $19,463-513$

GAO, R., XIAO, L., WANG, G.C., CAO, S.Z., LUO, Y.J., YUAN, J. \& HE, Q. (2009): Geochemistry, petrogenesis and significance of Late Paleozoic basalts in Kokshal district, South Tianshan mountains.- Journal of Mineralogy and Petrology, 29/2, 96-107 (in Chinese with abstract).

GREENOUGH, J.D. \& MCDIVITT, J.A. (2018): Earth's evolving subcontinental lithospheric mantle: inferences from LIP continental food basalt geochemistry.- International Journal of Earth Sciences, 107, 787-810

HAWKESWORTH, C.J., GALLAGHER, K., HERGT, J.M. \& MCDERMOTT, F. (1993): Mantle and Slab Contributions in ARC Magmas.- Annual Review of Earth and Planetary Sciences, 211/1, 175-204. doi: 10.1146/annurev.ea.21.050193.001135

HOU, Z.Q., QU, X.M., ZHOU, J.R., YANG, Y.Q., HUANG, D.H, LV, Q.F., TANG, S.H., YU, L.J., WANG, H.P. \& ZHAO, J.H. (2001): Collision-Orogenic Processes of the Yidun Arc in the Sanjiang Region: Record of Granites.-Acta Geologica Sinica, 75(04), 484-497 (in Chinese with English abstract).

HU, Z.C., LIU, Y.S., CHEN, L., ZHOU, L., LI, M., ZONG, K.Q., ZHUA, L.Y. \& GAO, S. (2011): Contrasting matrix induced elemental fractionation in NIST SRM and rock glasses during laser ablation ICP-MS analysis at high spatial resolution.Journal of Analytical Atomic Spectrometry, 26/2, 425-430. Doi: 10.1039/ C0JA00145G

IRVINE, T.N. \& BARAGAR, W.R.A. (1971): A guide to the chemical classification of the common volcanic rocks.- Canadian Journal of Earth Sciences, 8/5, 523-548. doi: 10.1139/e71-055

JACKSON, S.E., PEARSON, N.J., GRIFFIN, W.L. \& BELOUSOVA, E.A. (2004): The application of laser ablation-inductively coupled plasma-mass spectrometry to in situ U-Pb zircon geochronology.- Chemical Geology, 211, 47-69.

JUNG, S. \& MASBERG, P. (1998): Major-and trace-element systematics and isotope geochemistry of Cenozoic mafic volcanic rocks from the Vogelsberg (central Germany): constraints on the origin of continental alkaline and tholeiitic basalts and their mantle sources.- Journal of volcanology and geothermal research, 86/1, $151-177$.

KHOSHNOODI, K., BEHZADI, M., MARAGHEH \& G-M., YAZDI, M. (2017): Alkali Metasomatism and Th-REE Mineralization in the Choghart deposit, Bafq district, Central Iran.- Geologia Croatica, 70/1, 53-69. doi: 10.4154/gc.2017.03

KISS, G.B., MOLNÁR, F. \& PALINKAŠ, L.A., (2016): Hydrothermal processes related to some Triassic and Jurassic submarine basaltic complexes in northeastern Hungary, the Dinarides and Hellenides.- Geologia Croatica, 69/1, 39-64. doi: $10.4154 / \mathrm{gc} .2016 .04$

LASSITER, J.C., \& DEPAOLO, D.J. (1997): Plume/lithosphere interaction in the generation of continental and oceanic flood basalts: Chemical and isotopic constraints.- Geophysical Monograph Series, 100, 335-355. doi: 10.1029/ GM100p0335

LI, S.G. (1993): Ba-Nb-Th-La diagrams used to identify tectonic environments of ophiolite--Acta Petrologica Sinca, 9/2, 146-157 (in Chinese with abstract).

LI, Z.X., LI, X.H., ZHOU, H.W. \& KINNY, P.D. (2002): Grenvillian continental collision in south China: new SHRIMP U-Pb zircon result and implication for the configuration of Rodinia.-Geology, 30/2, 163-166. doi: 10.1130/0091-7613(2002)030\%3C0 163:GCCISC $\% 3 \mathrm{E} 2.0 . \mathrm{CO} ; 2$
LIANG, Q., YANG, W.X., YAN, D.P., MICHAEL, L.W., QIU, J.T., GAO, T., DONG, J.M., ZHANG, L.L. \& WANG, F.Y. (2018): Geochronology of early Mesozoic diabase units in southwestern China: metallogenic and tectonic implications.- Geol. Mag., 1-16.

LIU, H., WANG, G.C., CAO, K., MENG, Y.N., WANG, A. \& ZHANG, K.X. (2010): The detrital zircon fission-track ages constraint to tectonic processes in west Kunlun and adjacent regions.- Earth Science Frontiers, 17/3, 64-78 (in Chinese with English abstract).

LUDWIG, K.R. (2012): User's manual for Isoplot/Ex Rev. 3.75 A geochronological toolkit for microsoft excel. Berkeley Geochronology Center, Special Publication no. 5, $70-86$.

MA, X.X., DONG, C.W., ZHOU, C., LV, Q., GU, H.Y. \& WU, W.W. (2017): The Neoproterozoic continental rift magmatism of the eastern Jiangnan orogen: new evidence from the mafic sheets in northern Zhejiang Province, South China.- International Geology Review, 59/7, 829-844. doi: 10.1080/00206814.2016.1232180

MACDONALD, R., ROGERS, N.W., FITTON, J.G., BLACK, S. \& SMITH, M. (2001): Plume-Lithosphere Interactions in the Generation of the Basalts of the Kenya Rift, East Africa.- Journal of Petrology, 42, 877-900.

MAHONEY, J.J., JONES, W.B., FREY, F.A., SALTERS, V.J.M., PYLE, D.G. \& DAVIES, H.L. (1995): Geochemical characteristics of lavas from Broken Ridge, the Naturaliste Plateau and southernmost Kerguelen Plateau: Cretaceous plateau volcanism in the southeast Indian Ocean.- Chemical Geology, 12, 315-345. doi: 10.1016/00092541(94)00144-W

MANIAR, P.D. \& PICCOLI, P.M. (1989): Tectionic discrimination in of granitoids.- Geological Society of America Bulletin, 101, 635-643.

MESCHEDE, M. (1986): A method of discriminating between different types of mid-ocean ridge basalts and continental tholeiites with the Nb-Zr-Y diagram.- Chemical Geology, 56, 207-218.

MIDDLEMOST, E.A.K. (1994): Naming materials in the magma/igneous rock system.Earth-Science Reviews, 37(3-4), 215-224. doi: 10.1016/0012-8252(94)90029-9

MILLER, C., SCHUSTER, R., KLÖTZLI, U., FRANK, W. \& PURTSCHELLER, F. (1999): Post-Collisional potassic and ultrapotassic magmatism in SW Tibet: Geochemical and $\mathrm{Sr}-\mathrm{Nd}-\mathrm{Pb}-\mathrm{O}$ isotopic constraints for mantle source characteristics and petrogenesis.- Journal of Petrology, 40/9, 1399-1424. doi: 10.1093/petroj/40.9.1399

PEARCE, J.A. (1982): Trace element characteristics of lavas from destructive plate boundaries. Thorps R S. Andesites. New York: John Wiley and Sons, 525-548.

PEARCE, J.A. \& CANN, J.R. (1973): Tectonic setting of basic volcanic rocks determined using trace element analyses.- Earth and Planetary Science Letters, 19, 290-300. doi: 10.1016/0012-821X(73)90129-5

PEARCE, J.A., \& NORRY, M.J. (1979): Petrogenetic implications of Ti, Zr, Y, and Nb variations in volcanic rocks.- Contributions to Mineralogy and Petrology, 69/1,3347. doi: 10.1007/BF00375192

PECCERILLO, A. \& TAYLOR, S. (1976): Geochemistry of Eocene calc-alkaline volcanic rocks from the Kastamonu area, Northern Turkey.-Contributions to Mineralogy and Petrology, 58/1, 63-81. doi: 10.1007/BF00384745

RACZEK, I., STOLL, B., HOFMANN, A.W. \& JOCHUM, K.P. (2010): High-precision trace element data for the USGS reference materials BCR-1, BCR-2, BHVO-1, BHVO-2, AGV-1, AGV-2, DTS-1, DTS-2, GSP-1 and GSP-2 by ID-TIMS and MICSSMS.- Geostandards \& Geoanalytical Research, 25/1, 77-86. doi: 10.1111/j.1751-908X.2001.tb00789.x

SAUNDERS, A.D., FITTON, J.G., KERR, A.C., NORRY, M.J. \& KENT, R.W. (1997): The north Atlantic igneous province.- Geophysical Monograph Series, 100, 45-94. doi: 10.1029/GM100p0045

SHERVAIS, J.W. (1982): Ti-V plots and the petrogenesis of modern and ophiolitic lavas.Earth Planet. Sci. Lett., 59, 101-118. doi: 10.1016/0012-821X(82)90120-0

STOREY, B.C. \& KYLE, P.R. (1997): An active mantle mechanism for Gondwana breakup.- South African Journal of Geology, 100/4, 283-290.

SUN, S.S. \& MCDONOUGH, W. (1989): Chemical and isotopic systematics of oceanic basalts: implications for mantle composition and processes.- Geological Society, London, Special Publications, 42/1, 313-345. doi: 10.1144/GSL.SP.1989.042.01.19

SUN, S.Q., WANG, Y.L. \& ZHANG, C.J. (2003): Discrimination of the tectonic setting of basalts by $\mathrm{Th}, \mathrm{Nb}$ and $\mathrm{Zr}$-- Geological Review, 49/1, 40-47 (In Chinese with abstract).

SUN, W.H., ZHOU, M.F., GAO, J.F., YANG, Y.H., ZHAO, X.F. \& ZHAO, J.H. (2009): Detrital zircon U-Pb geochronological and Lu-Hf isotopic constraints on the Precambrian magmatic and crustal evolution of the western Yangtze Block, SW China.Precambrian Research, 172, 99-126. doi: 10.1016/j.precamres.2009.03.010

SZABÓ, B., SCHUBERT, F., TÓTH, T. M., STEINBACH, G. (2016): Palaeofluid evolution in a fractured basalt hosted reservoir in the Üllés-Ruzsa-Bordány area, southern sector of the Pannonian Basin.- Geologia Croatica, 69/3, 281-293. doi: 10.4154/ gc. 2016.25

TAYLOR, S.R. \& MCLENNAN, S.M. (1995): The geochemical evolution of the continental crust. - Review of Geophys., 33/2, 241-265. doi: 10.1029/95RG00262

WANG, C., LIU, H., DENG, J.H., LIU, X.F., ZHAO, F.F., WANG, C. \& TIAN, X. (2018): Isotope Geochronologic and Geochemical Constraints on the Magmatic 
Associations of the Collisional Orogenic Zone in the West Kunlun Orogen, China.Acta Geologica Sinica (English Edition), 92/2, 482-498.

WANG, K., PLANK, T., WALKER, J.D. \& SMITH, E.I. (2002): A mantle melting profile across the Basin and Range, SW USA.- Journal of Geophysical Research, 107(B1), 2017. doi: 10.1029/2001JB000209

WANG, Y.L., ZHANG, C.J \& XIU, S.Z. (2001): Th/Hf-Ta/Hf identification of tectonic srtting of basalts.- Acta Petrologica Sinica, 17/3, 413-421 (in Chinese with English abstract).

WEAVER, B.L. (1991): The origin of ocean island basalt end-member compositions: trace element and isotopic constraints.- Earth and Planetary Science Letters, 104/2, 381-397. doi: 10.1016/0012-821X(91)90217-6

WEAVER, S.D. \& JOHNSON, R.W. (1987): In tectonic controls on magma chemistry. Elsevier, Amsterdam, 161-176.

WEDENBECK, M., ALLE, P., CORFU, F., GRIFFIN, W.L., MEER, M., OBERLI, F., VONQUADT, A., RODDICK, J.C. \& SPEGEL, W. (1995): Three natural zircon standards for U-Th-Pb, Lu-Hf, trace element and REE analyse.- Geostandards and Geoanalytical Research, 19/1, 1-23. doi: 10.1111/j.1751-908X.1995.tb00147.x

WOOD, D.A. (1980): The application of a Th-Hf-Ta diagram to problems of tectonomagmatic classification and to establishing the nature of crustal contamination of ba- saltic lavas of the British Tertiary Volcanic Province.- Earth and Planetary Science Letters, 50, 11-30.

WU, L.N., WANG, Z.C. \& WANG, Y.L. (2003): On the application of La, Nb and Zr in identifying the tectonic settings.- Journal of East China Geological Institute, 26/4, 343-348.

XIE, X.J., YAN, M.C. \& WANG, C.S. (1989): Geochemical standard reference samples GSD 9-12, GSS 1-8 and GSR 1-6.- Geostandards and Geoanalytical Research, 13/1, 83-179. doi: 10.1111/j.1751-908X.1989.tb00469.x

YBGMRRGST, YUANNAN BUREAU OF GEOLOGY AND MINERAL RESOURCES OF REGIONAL GEOLOGICAL SURVEY TEAM. (2003): 1: 250000 Zhongdian County geological survey report (in Chinese).

ZHAO, X.F., ZHOU, M.F., LI, J.W., SUN, M.,GAO, J.F., SUN, W.H. \& YANG, J.H. (2010): Late Paleoproterozoic to early Mesoproterozoic Dongchuan Group in Yunnan, SW China: Implications for tectonic evolution of the Yangtze Block.- Precambrian Research, 182(1/2), 57-69. doi: 10.1016/j.precamres.2010.06.021

ZHOU, X., LI, Z.H., GERYA, T.V., STERN, R.J., XU, Z.Q \& ZHANG, J.J. (2018): Subduction initiation dynamics along a transform fault control trench curvature and ophiolite ages.- The Geological Society of America, 46/7, 607-610. doi: 10.1130/ G40154.1 